\title{
Depletion of groundwater resources under rapid urbanisation in Africa: recent and future trends in the Nairobi Aquifer System, Kenya
}

\author{
Samson Oiro ${ }^{1,2} \cdot$ Jean-Christophe Comte ${ }^{1} \cdot$ Chris Soulsby $^{1} \cdot$ Alan MacDonald $^{3} \cdot$ Canute Mwakamba $^{2}$
}

Received: 28 November 2019 / Accepted: 1 September 2020 / Published online: 3 October 2020

(C) The Author(s) 2020

\begin{abstract}
The Nairobi volcano-sedimentary regional aquifer system (NAS) of Kenya hosts $>6 \mathrm{M}$ people, including 4.7 M people in the city of Nairobi. This work combines analysis of multi-decadal in-situ water-level data with numerical groundwater modelling to provide an assessment of the past and likely future evolution of Nairobi's groundwater resources. Since the mid-1970s, groundwater abstraction has increased 10 -fold at a rate similar to urban population growth, groundwater levels have declined at a median rate of $6 \mathrm{~m} /$ decade underneath Nairobi since 1950, whilst built-up areas have increased by $70 \%$ since 2000. Despite the absence of significant trends in climatic data since the 1970s, more recently, drought conditions have resulted in increased applications for borehole licences. Based on a new conceptual understanding of the NAS (including insights from geophysics and stable isotopes), numerical simulations provide further quantitative estimates of the accelerating negative impact of abstraction and capture the historical groundwater levels quite well. Analysis suggests a groundwater-level decline of $4 \mathrm{~m}$ on average over the entire aquifer area and up to $46 \mathrm{~m}$ below Nairobi, net groundwater storage loss of 1.5 billion $\mathrm{m}^{3}$ and $9 \%$ river baseflow reduction since 1950. Given current practices and trajectories, these figures are predicted to increase six-fold by 2120 . Modelled future management scenarios suggest that future groundwater abstraction required to meet Nairobi projected water demand is unsustainable and that the regional anthropogenically-driven depletion trend can be partially mitigated through conjunctive water use. The presented approach can inform groundwater assessment for other major African cities undergoing similar rapid groundwater development.
\end{abstract}

Keywords Groundwater monitoring $\cdot$ Aquifer depletion $\cdot$ Conceptual model $\cdot$ Numerical modelling $\cdot$ Kenya

\section{Introduction}

The African population is heavily reliant on groundwater and this dependence is increasing with rapid population growth, especially around large cities (Foster et al. 2018). Rapid groundwater development can lead to falling water tables and aquifer depletion, and this has been observed in several

Electronic supplementary material The online version of this article (https://doi.org/10.1007/s10040-020-02236-5) contains supplementary material, which is available to authorized users.

Samson Oiro

koirosammy@gmail.com

School of Geosciences, University of Aberdeen, Scotland, UK

2 Water Resources Authority, Government of Kenya, Nairobi, Kenya

3 British Geological Survey, Lyell Centre, Edinburgh, Scotland, UK cities and their well fields, for example, Addis Ababa (Ethiopia), Nairobi (Kenya), and Dar es salaam (Tanzania; Adelana et al. 2008). However, detailed information and robust projections on both short- or long-term aquifer depletion are often lacking.

Aquifer depletion has become a major cause of concern globally (Konikow and Kendy 2005; Aeschbach-Hertig and Gleeson 2012; Famiglietti 2014). Over the last two decades, many studies based on in situ groundwater observations (Scanlon et al. 2012; MacDonald et al. 2016), regional to global-scale hydrological numerical models (Wada et al. 2010, 2014; Knowling et al. 2015; Wada 2016; de Graaf et al. 2017; de Salis et al. Cardoso de Salis et al. 2019), and/ or indirect satellite observations using GRACE (Rodell et al. 2009; Doell et al. 2014; Joodaki et al. 2014; Chen et al. 2016) have shown that many large sedimentary aquifers in arid and semi-arid regions, most of which also being subject to largescale irrigation, are undergoing depletion. 
In Sub-Saharan Africa, there are few long-term groundwater data to document the evolution of the groundwater response to abstraction. The few that do exist have highlighted some local depletion and provided evidence of the episodic nature of groundwater recharge in semi-arid areas (Cuthbert et al. 2019). In the absence of extensive monitoring evidence of long-term changes in aquifer storage have been provided by GRACE satellite observations interpreted with the help of land surface models (Resende et al. 2019). Such analyses suggest that change in storage in the large African aquifer systems is primarily driven by climate variability (Resende et al. 2019) and that none of them is undergoing significant depletion at a regional scale (Bonsor et al. 2018). The low spatial resolution/ large footprint of GRACE data $(400 \mathrm{~km}$ at the equator; Nanteza et al. 2016), however, restricts the estimations to large sedimentary aquifers and cannot resolve more localised subregional to regional depletion at the scale of a city, or in more complex, yet regionally to (trans)nationally important aquifer systems.

East Africa has relatively complex geology including volcanic, basement and narrow coastal sedimentary systems (MacDonald et al. 2012). However, unprecedented demographic growth rates in the region (Sub-Saharan Africa) are projected to add more than 0.5 billion people of the projected 1 billion of global population growth between 2019 to 2050 (United Nations 2019), which will translate into more pressure on groundwater resources. Kenya, in particular, has a deficiency in available water resources for meeting its growing demand, and most of the population of both rural and urban areas increasingly depends on groundwater supplies (Koei 2013). The lack of sufficient and consistent water supply by service providers in Kenya has forced the Kenyans to resort to private groundwater supplies in many urban and rural areas. The region underlain by the Nairobi Aquifer System (NAS) represents the largest area of demand with over 6 million people, most of which are already reliant on groundwater, and many industries and institutions.

Groundwater in the Nairobi area is geologically controlled with aquifer formations composed of fractured/weathered volcanic lava flows, pyroclastic deposits, interbedded sediments between volcanic layers, and lacustrine sediments (Kuria 2013), which defines the NAS covering an area of $5,880 \mathrm{~km}^{2}$. The NAS, through borehole abstraction, is a vital resource for the country's socio-economic development, supporting $60 \%$ of water needs in the region, i.e. an estimated 58 million $\mathrm{m}^{3}$ year (Mumma et al. 2011). By comparison, the recharge of the NAS is currently estimated to be between 109 million $\mathrm{m}^{3} /$ year according to Mumma et al. (2011) and 320 million $\mathrm{m}^{3} /$ year according to Koei (2013). It is also estimated that groundwater abstraction is rapidly increasing with a daily average of five new borehole drilling permit application being made from Water Resources Authority of Kenya (WRA) NAS area offices (Kiambu and Nairobi sub-regions; WRA,
"Nairobi sub-region and Upper Athi sub-region water right section application registry book", 2019). Given that, boreholes are mostly concentrated around Nairobi City County (NCC), suggesting that the NAS could be locally undergoing major and accelerating depletion, which could soon expand to larger regional scales and compromise environmental flows in the river network, not to mention the increasing risk of land subsistence in the most depleted areas. In addition to this, rapid urbanisation in the Nairobi region is responsible for major changes in land use, with a general decrease in forest cover and increase in build-up areas, which might contribute to groundwater level declines through modification of aquifer recharge patterns. More generally, the impacts of climate change and human activities on groundwater resources in Kenya and East Africa remain uncertain and quantitative studies are rare (Schaeffer et al. 2013; Comte et al. 2016). It is known, however, that groundwater abstraction increases during dry periods and decreases in rainy seasons in rural areas of Kenya (Thomson et al. 2019).

The research presented here investigates the multi-decadal impacts of increasing groundwater abstraction in the context of possible impacts of climate change and land use changes in the NAS. Nairobi and its underlying aquifer system can be considered typical of many other rapidly growing cities in Africa and the wider developing world. The main aim of the work is to establish the impact of the recent development of the NAS groundwater resource and assess its likely future evolution under alternative management scenarios. The specific objectives are: (1) to compare the long-term regional impact of observed climate variability, increased abstraction, and land use change on groundwater resources; (2) to locate and quantify possible areas of groundwater depletion; (3) to strengthen the hydrogeological conceptual understanding of the NAS, including aquifer heterogeneity and recharge processes; and (4) to apply a numerical groundwater model to estimate the long term aquifer budget and test alternative groundwater management scenarios. The study uses a multiproxy approach, integrating climatic records, land-use mapping, current and historical groundwater monitoring data and abstraction accounts, geophysical investigations, and stable isotope surveys, to underpin a numerical model of the groundwater system.

\section{The Nairobi Aquifer System}

\section{Geography}

The NAS is located in the Kenyan Highlands on the eastern flank of the Great Rift Valley, East Africa (Fig. 1). It occupies the northern part of Athi River basin which forms part of the five major basin areas of Kenya (Oiro et al. 2018). The elevation ranges from $1,400 \mathrm{~m}$ on the eastern floodplains near the 

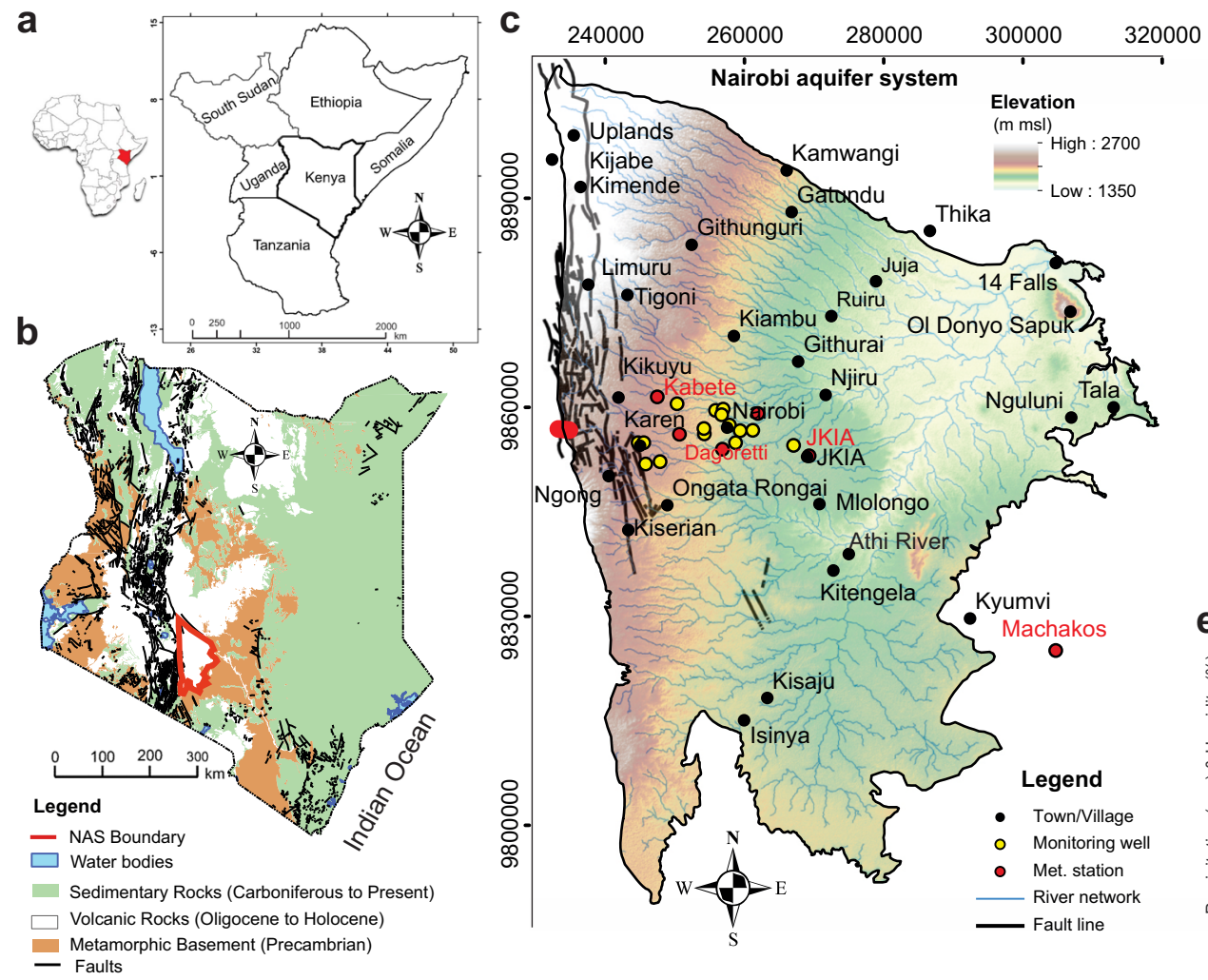

d

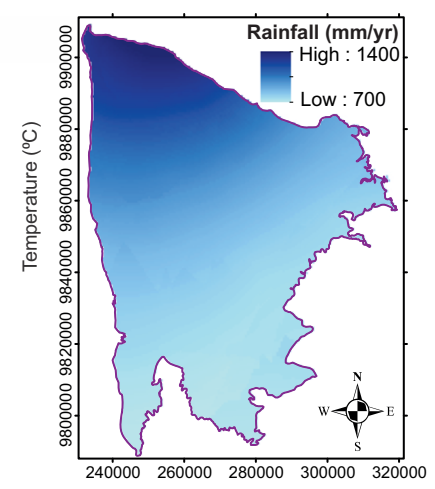

Fig. 1 General physical setting of the Nairobi Aquifer System (NAS): a location of Kenya in Eastern Africa, b simplified geological map of Kenya with outline of the NAS, c surface physical map of the NAS overlain with DEM ground elevation, drainage network, major faultrelated escarpments, key localities, Kenya Water Resource Authority

town of Athi River to 2,700 $\mathrm{m}$ in uplands areas of northwestern part of NAS, located within latitude $0^{\circ} 37^{\prime} 58^{\prime \prime}-1^{\circ} 59^{\prime} 23^{\prime \prime}$ south and longitude $36^{\circ} 34^{\prime} 27^{\prime \prime}-37^{\circ} 28^{\prime} 17^{\prime \prime}$ east. Over 6 million people live in the area with groundwater playing a major role in meeting their water needs (estimated to be about $60 \%$ of water supply within the aquifer area) as only $71 \%$ of the urban area (Nairobi City) is connected to piped water supply (Gulyani et al. 2005). The population density varies from 100 people per $\mathrm{km}^{2}$ in rural areas to over 4,500 persons per $\mathrm{km}^{2}$ in Nairobi.

\section{Climate}

The NAS area is subject to a subtropical montane climate. Average annual temperature ranges between $22-25^{\circ} \mathrm{C}$ (Fig. 1e). Occasional low temperatures however can reach $10^{\circ} \mathrm{C}$ in the coldest months (June/July). January to mid-March is the sunniest and warmest period with a mean temperature of $24{ }^{\circ} \mathrm{C}$, which precedes the heavy rainfall months of March to May (Fig. 1e). The annual average humidity follows the precipitation pattern and ranges between 60 and $84 \%$. The annual rainfall amount over the study area varies from $700 \mathrm{~mm}$ in the southeastern lowlands and floodplains, to over
(WRA) monitoring wells and Kenya Meteorological Department (KMD) weather stations, $\mathbf{d}$ spatial variability of average annual rainfall, e last 40 years' monthly averages of precipitation, humidity, and temperature

$1,400 \mathrm{~mm}$ on the northern highlands (Fig. 1d) with an average annual precipitation over the area estimated at $1,050 \mathrm{~mm}$. Heavy rains are concentrated in March to May, with a second peak in November resulting in an annual bi-modal distribution with flooding being experienced in lowland areas and within built-up areas during heaviest events (Oiro et al. 2018).

\section{Hydrogeological setting}

The geological formations constituting the Nairobi volcanosedimentary aquifer system were emplaced during the Tertiary and Pleistocene periods (Fig. 2). Tertiary formations include, the Kapiti phonolite, the Athi tuffs and lake beds, $\mathrm{Ol}$ Donyo Narok agglomerates, and the Ngong basanites. The Pleistocene formations comprise of the Mbagathi trachyte, the Nairobi phonolite, the Nairobi and Kiambu trachyte, the Limuru, Tigoni and Kabete trachytes, the Upper, Middle and lower Kerichwa tuffs, and Kijabe pyroclastic rocks and sediments (Oiro et al. 2018). The exposure time between successive volcanic units' deposition facilitated the creation of palaeo land surfaces and bedrock weathering between successive layers. The volcano-sedimentary aquifer system overlies Precambrian granitoid gneisses, which are part of the 


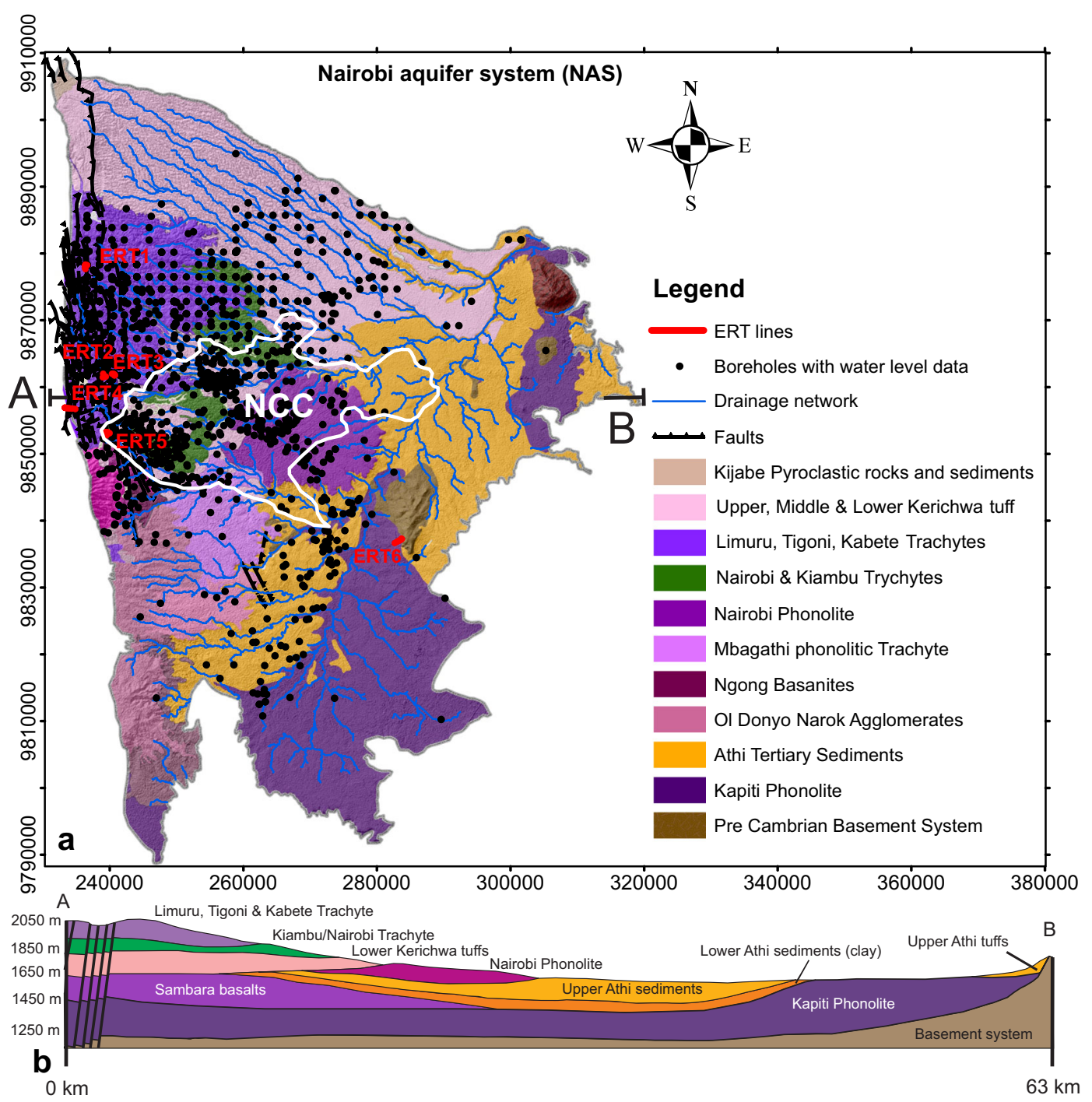

Fig. 2 a Geological map of the NAS overlain by WRA registered boreholes (black points), ERT transects acquired in this work (red lines; see ESM) and drainage network. NCC denotes Nairobi City County. b geological cross-section of the NAS from west (A) to east (B)

Mozambique belt basement system and produce low or nonyielding wells. The geomorphological evolution of the NAS has been controlled by volcanic activity and tectonic movements associated with the East Africa rift system (Gaciri and Davies 1993). Fault systems also associated with the East African rift affect the western part of the aquifer structure and are oriented north-south, parallel to the Rift Valley (Kuria 2013; Fig. 2). The eastern and southeastern part of the study area are underlain by the Athi sediments (Athi floodplains), the Nairobi phonolite and the Kapiti phonolite with an average elevation of $1,500 \mathrm{~m}$. The volcanosedimentary thickness approximates $400 \mathrm{~m}$ beneath the Nairobi City centre (Wamwangi and Musiega 2013), with a saturated thickness (total water column) of approximately $300 \mathrm{~m}$ at that location. The thickness of the aquifer units increases westwards away from the exposed Precambrian basement system in the east.
Primary cooling-contraction fissures and weathering of the lava flows along with pyroclastic layers and lake beds intergranular porosity form the main flow and storage features of the multi-layered, aquifer system (Oiro et al. 2018). A summary of the ranges in hydraulic properties of the NAS was drafted in the Kenya Groundwater Governance Study report (Mumma et al. 2011) as shown in Table 1. They are spatially variable due to the complex architecture of volcanosedimentary units and the fracture distribution (Coleman et al. 2015; Dailey et al. 2015; Ochoa-González et al. 2015). Transmissivity values range from $10^{-6}$ to $2 \times 10^{-3} \mathrm{~m}^{2} / \mathrm{s}$. The upper Athi sedimentary series generally provide the highest yields with a range of transmissivity values between 6 and $60 \times 10^{-5} \mathrm{~m}^{2} / \mathrm{s}$ (Okoth 2012). Storativity values range between $10^{-4}$ and $10^{-1}$, characteristic of unconfined to semiconfined conditions. Semi-confining conditions are found beneath the Athi sediments (Fig. 2), where the Lower Athi clays 
Table 1 Summary of the NAS general hydrogeological characteristics as reported in the Kenya Groundwater Governance Study report (updated from Mumma et al. 2011)

\begin{tabular}{ll}
\hline Parameter & Classification \\
\hline Aquifer type & Inter-montane valley fill \\
Lithology & Lavas and lake sediments \\
Dominant flow regime & Inter-granular/fissure \\
Scale & Regional \\
Transmissivity $T, \mathrm{~m}^{2} / \mathrm{s}$ & $1.2 \times 10^{-6}-1.8 \times 10^{-3}\left(\right.$ median $\left.3.9 \times 10^{-5}\right)$ \\
Hydraulic conductivity $K,(\mathrm{~m} / \mathrm{s})$ & $1.2 \times 10^{-7}-1.5 \times 10^{-5}$ \\
Storage coefficient $S$, ratio & $1.2 \times 10^{-4}-4.2 \times 10^{-1}\left(\right.$ median $\left.1.1 \times 10^{-2}\right)$ \\
Diffusivity $T / S, \mathrm{~m}^{2} / \mathrm{s}$ & $370-830(300)$ \\
Recharge, $\mathrm{mm} /$ year & 16.8 \\
\hline
\end{tabular}

act as a semi-confining unit for the underlying Sambara basalt-Kapiti Phonolite aquifer (Mumma et al. 2011). The semi-confining conditions are indicated by the existence of artesian wells in the Nairobi area and rest water levels rising above the struck levels (cf. WRA borehole completion reports/records, 1940-2020).

Most boreholes in the NAS are drilled down to tap the Sambara basalt-Kapiti phonolite aquifer but are usually screened at multiple depths tapping both deep and shallow water-bearing formations without distinction (WRA borehole completion reports).

To the west, the densely north-south-faulted volcanic rocks associated with vertical displacements on the flanks of the Rift Valley generate springs and artesian wells (Oiro et al. 2018). Rift-associated faults and fractures also constitute preferential recharge pathways in the area (Lane et al. 2011). According to Odero (2011), they also locally reorient the flow direction to NE-SW and N-S. Elsewhere, well-drained volcanic soils and fault density favour diffuse groundwater recharge during rainy seasons (Kuria 2013). Faults and fissure zones facilitate infiltration into deeper aquifer layers/ formations as groundwater pathways (Okoth 2012; Kuria 2013; Oiro et al. 2018) and ensures annual aquifer recharge. Mumma et al. (2011) estimated an average annual recharge over the aquifer area of $17 \mathrm{~mm} /$ year, which is lower than the more recent, national-scale and spatially coarser estimates by Koei (2013) and ISC (2019) providing values ranging between 15 and $120 \mathrm{~mm} /$ year from southeast to northwest direction.

\section{Methods}

\section{Climatic trend analysis}

Climatic data from seven meteorological stations within the NAS were purchased from the meteorological department of Kenya and analysed for the period 1970 to 2014 (44 years), one of which was completed up to 2019 from open-access data available from World Weather Online (2019). Precipitation data were available for the seven stations, temperature data for six stations, and open pan evaporation data for five stations. The data were summarised on a monthly basis and ranged from different years with precipitation records covering 1970-2014 (44 years) for six stations and 1970-2019 (49 years) for one (Kabete), evaporation 1974 2014 (40 years), and temperature 1980-2014 (34 years). They were subsequently summed to derive annual totals. Statistical linear trends were generated from combining data from all stations and linear regressions were performed and analysed using SPSS Statistics ver. 26. Climate trends for the historical period were analysed to identify the possible impact of climatic change on groundwater recharge and its eventual impact on groundwater storage through recharge and/or evapotranspiration. Deviations to linear trends were ultimately used for discussing the historical variations within climatic data and possible impacts on the groundwater resource. Additionally, the monthly precipitation data for Kabete station (Kabete), which had the most recent records up to 2019, were further used in specifically investigating the possible link between climatic conditions and new borehole permit applications available for the period 2010-2019.

\section{Land-use change mapping}

Landsat images for 2000 and 2017 were downloaded from the EarthExplorer website (USGS 2018) for land-use classification. Using ESRI software ArcGIS v10.5, the images were merged, then clipped for the area of interest. These were then classified using conversion of categorised classes of land cover. In the GIS, polygons were drawn for classes derived from raster input data. Drawn signature polygons were grouped into forest, built-up areas, and others (waterbody, grassland and shrubs). Signatures were created using multivariate statistics for maximum likelihood classification of the captured data. The resulting classified image map was then used, and the surface areas of the different land-use categories were calculated to quantify land-cover changes over the 17 years period. 


\section{Spatiotemporal analysis of groundwater data}

\section{Groundwater abstraction records and trend analysis}

Groundwater abstraction data for the NAS were obtained from the WRA. These data are compiled from water use permit applications and meter readings obtained for billing and are stored in a water permit database (PDB). Records of the quality of groundwater abstraction commenced in 2012 by WRA and, by 2017 , the new permit application records and existing records of abstraction data were considered almost complete. To get the best possible estimate of the volume abstracted over the years, borehole records and drilling permit application rates have been used. The PDB records were then recompiled into annual abstractions to understand the exploitation trend using nonlinear regression. This approach has potential limitations because most boreholes are not recorded in the WRA borehole database (borehole completion reports) and are known to be pumping without any permit; therefore' the PDB significantly underestimate the real abstraction. To account for this, an abstraction average of $20 \mathrm{~m}^{3} /$ day (mostly applied for by private borehole owners when seeking abstraction permit from the government) was assumed from each recorded borehole, multiplied by the estimated number of boreholes in the area for different periods. It is however acknowledged that most private owners do not abstract as high as permitted (WRA 2020). On the other hand, water service providers and institutions like hospitals, schools, universities, and industries do abstract more than this. Hence, $20 \mathrm{~m}^{3} /$ day was assumed a realistic average value of abstraction per borehole; additionally, the permit application records available since 2019 were summed into number of monthly applications for comparison with monthly rainfall over the same period. Finally, in order to highlight possible correlation between the groundwater abstraction trend and population growth, the estimated abstraction for the NAS was further compared to available past and projected (1950-2035) population data for NCC, as provided by the United Nations" "2018 Revision of World Urbanization Prospects" (United Nations 2018) and the Nairobi projections for 2100 by the Global Cities Institute (Hoornweg and Pope 2014; Hoornweg and Pope 2017).

\section{Groundwater level time series}

The long-term historical evolution of groundwater conditions was interpreted from primary data obtained from monitored groundwater levels. Groundwater monitoring data collected monthly by the WRA at sub-regional level (Nairobi Subregion Office) were compiled. WRA provided monitoring data for over 10 years (2006-2017) for 15 observation points across the NAS (see Figs. 1 and 3b). The groundwater levels were provided in metres below ground surface. All these wells are located in residential areas, and are productive wells a
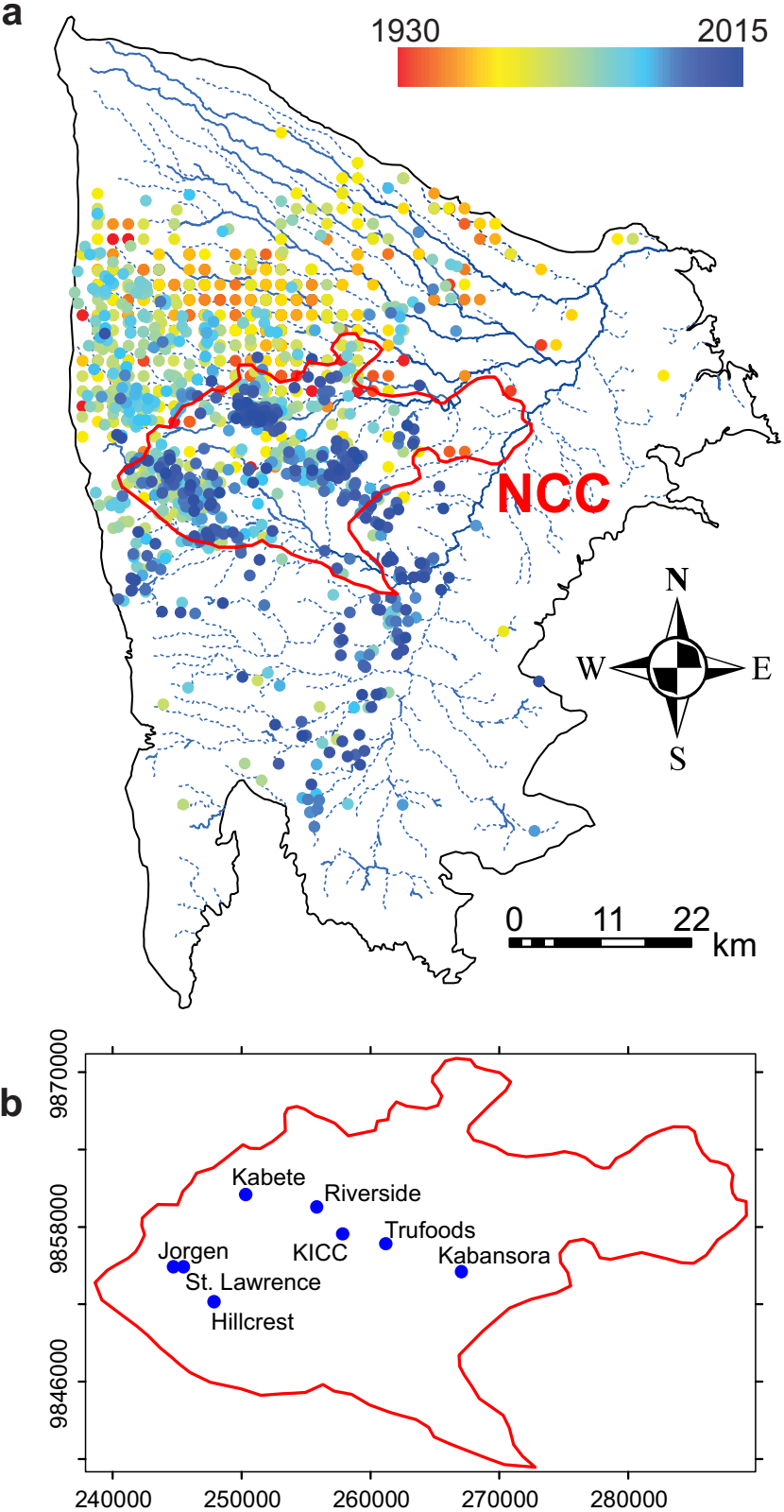

Fig. 3 a Location of the 1,520 pumping wells having water level measurement with observation date indicated in graded colour, along with permanent and temporary rivers indicated as continuous and dashed blue lines, respectively; b location of temporally monitored wells within the NCC

surrounded by other pumping boreholes, which indicates a monitoring of dynamic groundwater levels rather than static. Pumping schedules on the observation wells caused high frequency (daily of less) drawdown/recovery patterns that complicated the identification of long-term trends. Therefore, all observation points (seven) showing strong (high frequency) pumping influence were eliminated and the eight remaining points showing longer-term fluctuations with no or moderate short-term pumping influence have been used for trend analysis and model calibration. 


\section{Mapping of groundwater level change}

Piezometric maps of the NAS for specific years $(1950,1960$, 1970, 1990, and 2015) were generated from interpolation with a GIS using point groundwater levels compiled from both the borehole completion reports and the data from the groundwater monitoring network available at WRA. The 1950 map included 449 piezometric data covering the period 1939 to 1955; the 1960 map included 168 piezometric data covering the period 1956 to 1965 ; the 1970 map included 194 piezometric data covering the period 1966 to 1980 ; the 1990 map included 538 piezometric data covering the period 1981 to 2000; and the 2015 map included 1,266 piezometric data covering the period 2001 to 2015 . The groundwater level data were expressed in metres below ground surface as obtained from dip-meters $( \pm 1 \mathrm{~cm})$ and their respective geographic coordinates were originally captured using hand-held GPS $( \pm 5 \mathrm{~m})$. The groundwater level data were further converted to absolute water elevation using raster data extracted from $30 \mathrm{~m} \times 30 \mathrm{~m}$ resolution DEM with a vertical accuracy of $\pm 1 \mathrm{~m}$. Kriging was employed to interpolate from point absolute groundwater level elevations and generate potentiometric surface maps for respective periods. To assess the increase or decrease in groundwater levels over time, the differences between two successive periods (as well as present vs. oldest records) were obtained and mapped. Quantitative analysis of groundwater level changes was restricted to NCC area as it is well constrained with piezometric points. The NCC mean groundwater level change was generated for each period of interest $(1950,1970,1990,2015)$ using ArcGIS zonal statistics extensions.

\section{Groundwater numerical modelling}

\section{Modelling code and calibration}

Visual MODFLOW Flex 5.1 software was used for carrying out the 3D numerical groundwater flow simulations. The MODFLOW-2005 finite-difference engine was used in the general case of variable unconfined/confined conditions. Model calibration was performed through trial-and-error procedure and comparison of calculated versus observed heads using known ranges of values aquifer hydrodynamic properties (hydraulic conductivity, specific storage and specific yield). Steady-state simulations with no abstraction were first carried out to create initial conditions representative of years pre-1950 (before large-scale groundwater development). Thereafter, successive historical transient simulations were carried out incorporating the exponential rate of groundwater development and abstraction. The model with best fit (in terms of calculated versus observed heads) was retained for historical and future simulations presented in the section 'Results'. Because of the lack or reliable data on aquifer storativity, and particularly specific yield Sy, a sensitivity analysis was carried using two alternative min-max Sy scenarios. Model calibration results and plots are presented and discussed in section 'Model calibration results'.

\section{Aquifer structure and distribution of hydrodynamic parameters}

Volcanic sequences identified from well-logs, point data and geological maps and geological cross-section (Fig. 3) as well as new geophysical data - see the electronic supplementary material (ESM) - were converted to nine layers within Visual MODFLOW. Using a cell size of $1,000 \mathrm{~m} \times 1,000 \mathrm{~m}$, a total number of 5,830 cells were defined per layer, which amounts to a total number of 52,470 cells for the whole threedimensional (3D) model domain. Theis and PapadopoulosCooper methods were applied using AQTESOLV software to estimate transmissivity (T) from borehole completion reports. Papadopoulos-Cooper method was specifically applied to the confined (and nonleaky) regions of the aquifer, while the Theis method was applied to the unconfined parts. Hydraulic conductivity $(\mathrm{K})$ values were then calculated using the relationship between transmissivity and hydraulic conductivity where $T=K \cdot b$, with $b$ being the saturated aquifer thickness. Initial hydraulic conductivities $\mathrm{K}$ were assigned to model layers as synthesized from pumping test interpretations compiled in the WRA borehole completion reports. As they displayed a range of values for the same geological unit, the geometric mean was applied to the corresponding layer (see section 'Model calibration results'). For storage properties, due to the lack of reliable estimates, initial values for the specify storage Ss and specific yield Sy both used the mean storage coefficient $S$ as provided by Mumma et al. (2011), Table 1 . Subsequently, $\mathrm{K}$ values were recalibrated through trial-and-error per model geological layer, while for Sy, they were recalibrated considering a simpler two-layer scenario accounting for decrease in Sy with depth (section 'Model calibration results'). Two typical high/low Sy values of 0.1 and 0.01 were chosen for the upper and lower aquifer, respectively, to reflect the typical variability as obtained from a synthesis of literature values for volcanic rocks, including the existing few data for the NAS (Heath 1987; Mumma et al. 2011); and confining conditions (i.e. $S=b \cdot$ Ss) were applied beneath the Athi sediment conformably to the hydrogeological conceptual model (section 'Hydrogeological setting'). In addition, two alternative, unconfined and uniform Sy distributions (using the max-min values of 0.1 and 0.01 , respectively) were considered in order to account for the range of uncertainty in Sy associated with the poor in situ information available, and further provide min-max envelopes of predicted long-term aquifer storage change. 


\section{Model boundary conditions}

No-flow and river boundaries No-flow geological boundaries were assigned along (1) the contact between the volcano-sedimentary aquifer and the underlying basement system to the East and South East which defines the base of the model, (2) the western boundary defined along the Great Rift Valley eastern flank, and (3) the regional groundwater divide to the North (WRA aquifer maps, 2012). Apart from the groundwater divide in areas of no clear structural boundary, the ERT geophysical profiles carried out in the basement and rift area (see ESM) were further used to support the decision to have the Rift Valley eastern flank as the western boundary and the basement outcrop as an erosion surface for the southeastern aquifer boundary. The rivers were applied as drain boundary conditions (Fig. 3a) in order to allow for groundwater discharge as suggested by water stable isotope analysis for groundwater and rivers in the area, which showed clear evidence of groundwater discharge to surface water bodies (Oiro et al. 2018), and supported by geophysical data (see ESM).

Abstraction wells At present, over 7,000 pumping wells are actively abstracting groundwater in the NAS. Using all active wells as pumping wells would require a very fine cell size, which would be computationally demanding and unrealistic; therefore, it was decided to use a relatively coarse regular cell size (as described previously) and to define clustered pumping wells (76 in number) based on the borehole density and the cumulative increase of production wells of the area. Using the estimated pumping rate of 20 $\mathrm{m}^{3} /$ day for each well, the abstraction rates per clustered well over the scheduled periods were generated as a product of number of boreholes and $20 \mathrm{~m}^{3} /$ day, a rate chosen as the standard rate applied for by private borehole owners to the WRA permit applications procedure. However, the uncertainty surrounding the estimated averaged abstraction rate per borehole is variant as some private borehole owners abstract less than the estimate, while water service providers, institutions of learning, health facilities, industries and agricultural sectors (such as flower farms) abstract much higher amounts. When compared to the category abstraction, the averaged estimated $20 \mathrm{~m}^{3} /$ day has been reasonably assumed to be near the averaged reality. Total estimated abstraction rate per respective scheduled period listed above are $16,120 \mathrm{~m}^{3} /$ day $(1950-1960), 24,080 \mathrm{~m}^{3} /$ day (1960-1970), 50,080 $\mathrm{m}^{3} /$ day (1970-1990), $92,840 \mathrm{~m}^{3} /$ day (1990-2015) and 140,140 $\mathrm{m}^{3} /$ day (2015-2018). Boreholes with dated groundwater level measurements were used as calibration dataset. A total of 1,520 observations data points was used with their respective observation dates (measurement made shortly after drilling completion) ranging from the year 1939-2015.
Groundwater recharge The Koei (2013) 'Kenya National Water Master Plan' study estimated Kenyan groundwater recharge at $5 \%$ of precipitation on average. The NAS area receives an average annual rainfall of $1,000 \mathrm{~mm}, 5 \%$ of which translates to recharge rate of $50 \mathrm{~mm} /$ year. This mean recharge value was used in subsequent numerical modelling instead of the value reported by Mumma et al. (2011) in Table 1. JICA team obtained groundwater recharge through rainfall-runoff analysis using the similar hydrologic element response (SHER) model by simulating basin-scale hydrology and was deemed more reliable at regional scale. JICA derived their value using FAO Penman-Monteith and Hamon's method through estimated evapotranspiration using available climatic data, while Mumma's calculations are not described.

Seven recharge zones were further spatially delineated from the joint use of the NAS rainfall isohyet maps, the NAS isoscapes as identified in Oiro et al. (2018), the interpretation of geophysical results (which revealed preferential recharge pathways along the border of the rift valley in the west; see ESM) and the estimated water loss beneath NCC due to leaking pipes (not considering outside the city boundary). The zones were further used to compute recharge distribution for the groundwater simulations (see ESM).

\section{Future scenarios}

As for the historical simulation, three alternative models (the best calibrated historical model using layered Sy distribution of 0.1 in upper aquifer units in 0.01 in lower units along with confining conditions beneath the Athi sediments; and two, unconfined uniform Sy models of 0.1 and 0.01) were used for simulating the probable evolution of groundwater resources under future abstraction scenarios. The two tested scenarios of groundwater development were (1) continued increasing abstraction following a fitted cubic growth rate, assuming that estimated groundwater abstraction would continue to follow the predicted (cubic) population growth rate (groundwater-dependent scenario, GWDS), and (2) capped groundwater abstraction rate of 2018 with future increasing water needs met by increasing supplies from the Tana catchment outside the NAS (outsourced piped water supply; conjunctive water supply scenario, CWSS). The historical conditions pre-2018 for both scenarios were the same to date. The future water demands for the NAS area are expected to be met either by the existing piped water supply rate and increased groundwater abstraction or by increased outsourcing supply water from outside the catchment to meet the increasing demand. It was therefore assumed that increased piped water supply in the CWSS scenario will also be associated with increased groundwater recharge from leaking pipes and this expected increase was calculated based on projected Nairobi water demand (Table 2). For this, the currently planned outsourced water supply of an extra $140,000 \mathrm{~m}^{3} /$ day from 
Table 2 Scenario conditions applied to the numerical groundwater model (abstraction in $\mathrm{m}^{3} /$ day; recharge in mm/year; GWDS = groundwater dependent scenario; $\mathrm{CWSS}=$ conjunctive water supply scenario; $\mathrm{NCC}=$ Nairobi City County)

\begin{tabular}{lllllllllll}
\hline Scenario & \multicolumn{1}{l}{ Starting year } & & & & & \\
\cline { 2 - 9 } & 1950 & 1960 & 1970 & 1990 & 2015 & 2018 & 2035 & 2060 & 2090 & 2120 \\
\hline GWDS scenario & & & & & & & & & \\
Groundwater abstraction & 3,124 & 5,502 & 9,710 & 30,198 & 124,584 & 147,691 & 270,184 & 520,003 & 933,994 & $1,472,002$ \\
NCC recharge from leaking pipes & 50 & 50 & 52 & 54 & 57 & 60 & 60 & 60 & 60 & 60 \\
CWSS scenario & & & & & & & & & \\
Groundwater abstraction & 3,124 & 5,502 & 9,710 & 30,198 & 124,584 & 147,691 & 147,691 & 147,691 & 147,691 & 147,691 \\
NCC recharge from leaking pipes & 50 & 50 & 52 & 54 & 57 & 60 & 64 & 68 & 70 & 74 \\
\hline
\end{tabular}

the Northern Connector Tunnel by 2020 and an increased supply of $1,200,000 \mathrm{~m}^{3} /$ day by 2035 were used. After 2035, the 2018-2035 increasing trend was maintained. On the other hand, because the GWDS scenario considers that no additional water will be brought through pipes from the outside, this scenario assumes a constant recharge from leaking pipes from 2018 onwards.

\section{Results}

\section{Climatic trends}

Precipitation (seven meteorological stations) and evaporation (five meteorological stations) data available for the past 44 years did not reveal any statistically significant trend (Fig. 4a,c). Linear regression analysis with SPSS v26 (Table 4) showed insignificant change in annual rainfall $\left(R^{2}\right.$ of 0.071$)$ and evaporation $\left(R^{2}\right.$ of 0.224$)$, yielding values of $R^{2}$ of 0.071 and 0.224 , respectively. This means that only 1 and $22 \%$ of the observed variance in precipitation and evaporation respectively, can be predicted from a linear trend. In contrast, temperature time series from six meteorological stations showed a more significant increasing trend of $\sim 0.3^{\circ} \mathrm{C} / \mathrm{decade}$ over the 34 years of records available (Fig. 4b). The $R^{2}$ of 0.558 (Table 3 ) indicated that $56 \%$ of the observed variance in temperature can be predicted from a linear trend. This analysis implies high uncertainty in the climate trends in the region, and as a result, existing data do not allow for confidently estimating a possible influence on the long-term evolution of groundwater recharge.

\section{Land-use change}

The classification of land-use over the NAS focused on assessing changes in the spatial extent of built-up areas (urbanisation), forests and other vegetation (grasslands, agricultural land, and shrubs) over the 2000-2017 period (Fig. 5a,b). This is further summarised in Fig. 5c, revealing: (1) a $70 \%$
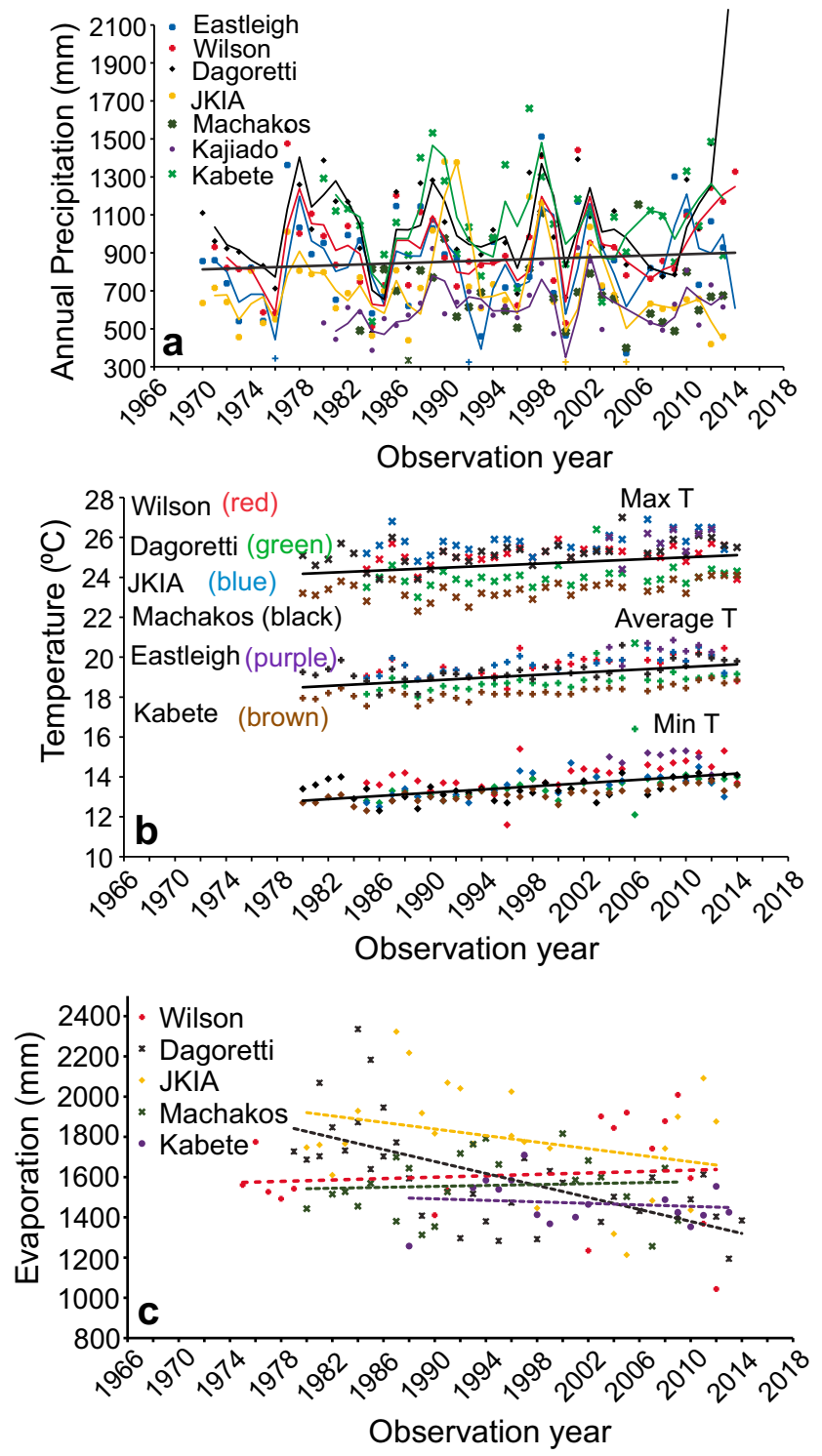

Fig. 4 a 1970-2014 annual precipitation for the NAS' seven weather stations with regional linear trendline, b 1980-2014 annual minimum, average, and maximum temperature for six stations with regional linear trendline, and c 1975-2014 annual evaporation for five stations with respective linear trendlines (pan evaporation) 
Table 3 SPSS linear regression parameters for the analysed averaged annual climatic data at $95 \%$ confidence interval $\left(R^{2}\right.$ is the coefficient of determination demonstrating whether observed values are regressed on predictions and Vis versa, while $R$ is the correlation between the predicted values and the observed values). $S D$ standard deviation

\begin{tabular}{llll}
\hline Parameter & Rainfall & Temperature & Pan evaporation \\
\hline Slope & 4.6 & 0.025 & -5.2 \\
$R^{2}$ & 0.071 & 0.558 & 0.224 \\
$R$ & 0.266 & 0.747 & 0.473 \\
Mean & 923 & 18.25 & 1609 \\
SD & 225 & 0.34 & 126 \\
\hline
\end{tabular}

increase of built up areas from $14.5 \%$ coverage in 2000 to $24.2 \%$ in 2017 , (2) a $23 \%$ decrease in forest cover from 2000 at $20.3-15.7 \%$ in 2017 , and (3) a small change in the combined coverage of grassland, agriculture and shrubs. The observed reduction of agricultural surfaces at the expense of constructed areas around the main urban centres mostly relate to coffee and tea farms and are likely to modify any hydroclimatic influences on the spatio-temporal patterns of groundwater recharge. The conversion from farmlands to housing also brought about more drilling of boreholes thereby expecting to be modifying the magnitude and spatial distribution of groundwater abstraction points.

\section{Groundwater abstraction and borehole permit application trends}

Early 2010 corresponded with the start of ongoing WRA efforts to obtain systematic recording of abstraction rates through progressive installation of a metering system (master meter readings). Master meters are installed at the source point (on-site metering) at every borehole (abstraction point) before distribution and any loss through leaky connections. This has yielded positive results with recorded abstraction in 2017 being close to estimates derived from approximations based on the borehole permit records available since the late 1970s (Fig. 6a), suggesting that the WRA abstraction record is nearing completion. The combination of both indicate rapidly increasing trends. Estimated groundwater abstraction (the most realistic estimate from borehole permit records and assumed averaged abstraction value of $20 \mathrm{~m}^{3}$ /day per borehole) suggests an (almost perfect; $R^{2}=0.9985$ ) increasing cubic trend in groundwater use throughout the 1977-2017 period, from about $14,500 \mathrm{~m}^{3} /$ day in late 1970 s to $150,000 \mathrm{~m}^{3} /$ day in 2017; i.e. an increase by a factor 10 in 40 years. Within the most recent period 2008-2019, for which permit applications for new boreholes is available from the WRA, the number of applications are increasing overall (Fig. 6b) consistent with the observed increasing abstraction. The number of permit applications however show a clear correlation with climatic conditions (Fig. 6b), whereby dry years are associated with, or immediately followed by, an increased number of applications.

The NAS estimated abstraction is following a trend similar to the NCC population data as reported in the 2018 "Revision of the UN World Urbanization Prospects" (United Nations 2018; Fig. 7a). Both are highly correlated with a $R^{2}$ of 0.996 (Fig. 7b). This confirms the key role of NAS groundwater in meeting the city's population increasing water demand and suggests that groundwater demand may reach $300,000 \mathrm{~m}^{3} /$ day by 2035 . When combining the UN population data and projections for 1950-2035 with the population projection for 2100 (Hoornweg and Pope 2014), the population growth trend
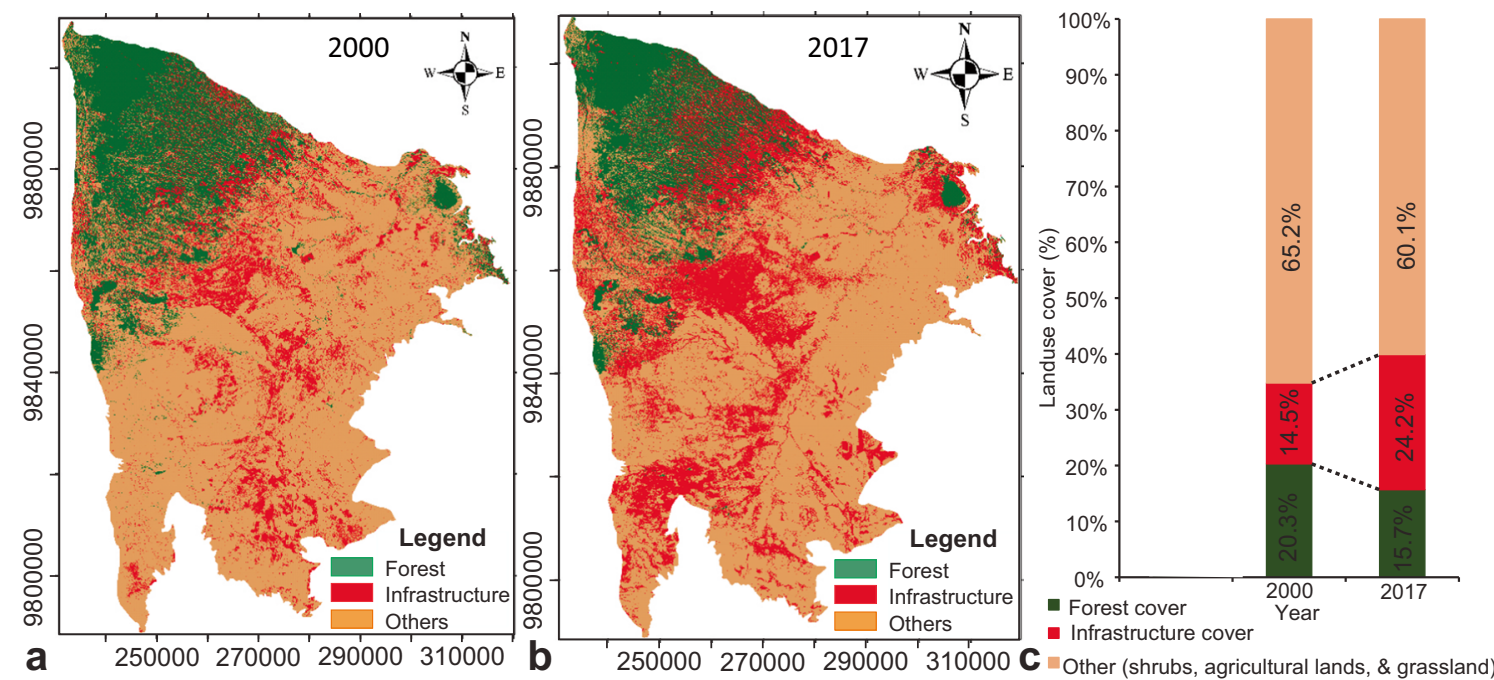

Fig. 5 Classified land-use cover and changes over the last two decades, a year 2000 land use map, which shows the least land cover under infraurban infrastructure, and $\mathbf{c}$ changes in the proportions of respective landuse categories over the 17-year period 
Fig. 6 a Estimated (using WRA boreholes completion reports) and recorded (using the WRA water permit database) daily groundwater abstraction showing the best fitted trends as dashed lines (cubic growth for estimated abstraction, $R^{2}=0.9985$; quadratic growth for recorded abstraction, $\left.R^{2}=0.9915\right)$, b Relationship between recorded monthly borehole permit applications and respective monthly average precipitation of Nairobi area for the last 10 years (January 2009-September 2019)

Fig. 7 Correlation between trends of NAS estimated abstraction and Nairobi City County (NCC) population; a past and projected NCC population according to the 2018 "Revision of the UN World Urbanization Prospects" (United Nations 2018) and Hoornweg and Pope (2014) (for Nairobi 2100 projected population), which follows a cubic growth, overlain with the NAS estimated abstraction; $\mathbf{b}$ linear correlation between NAS estimated abstraction and NCC population a

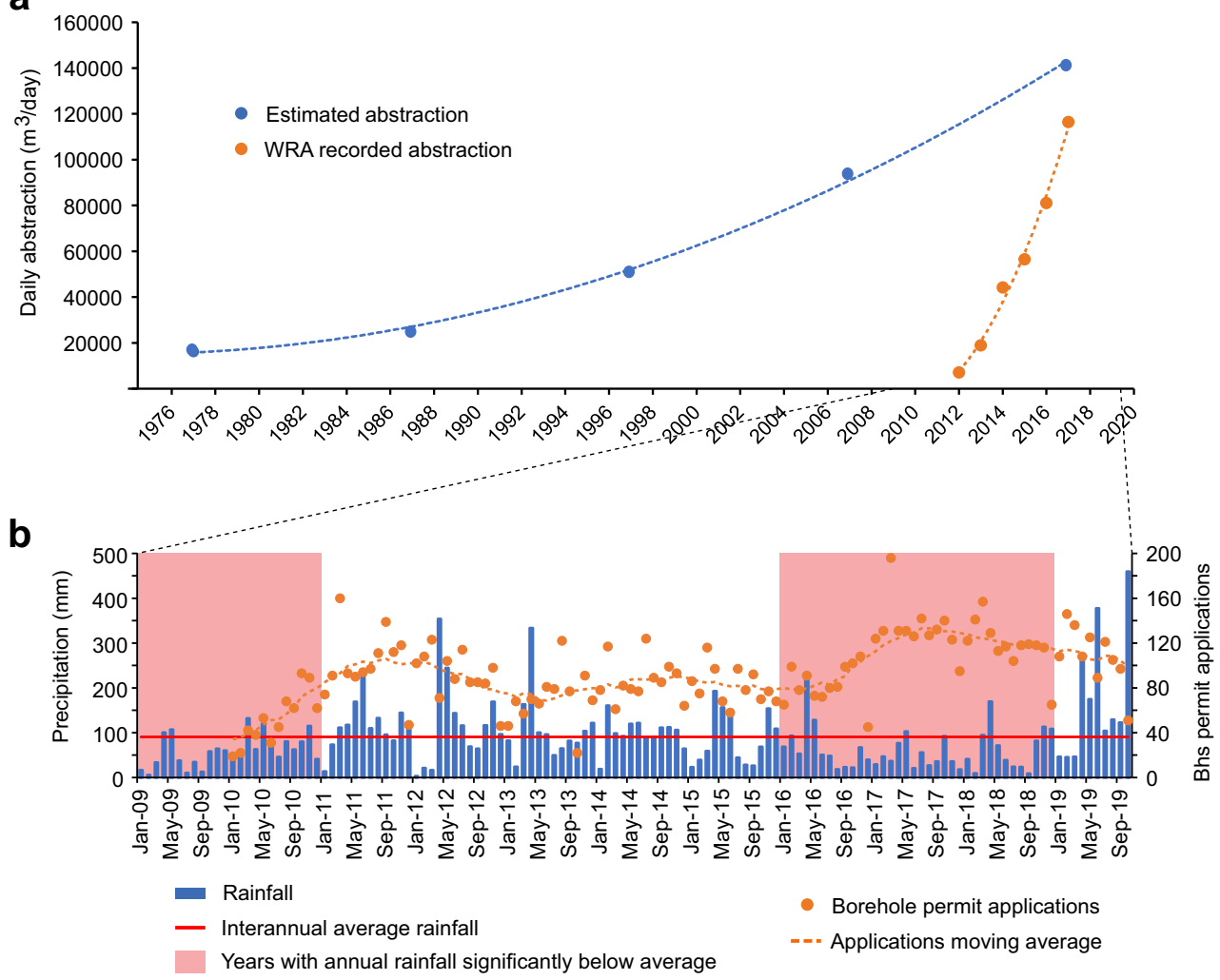

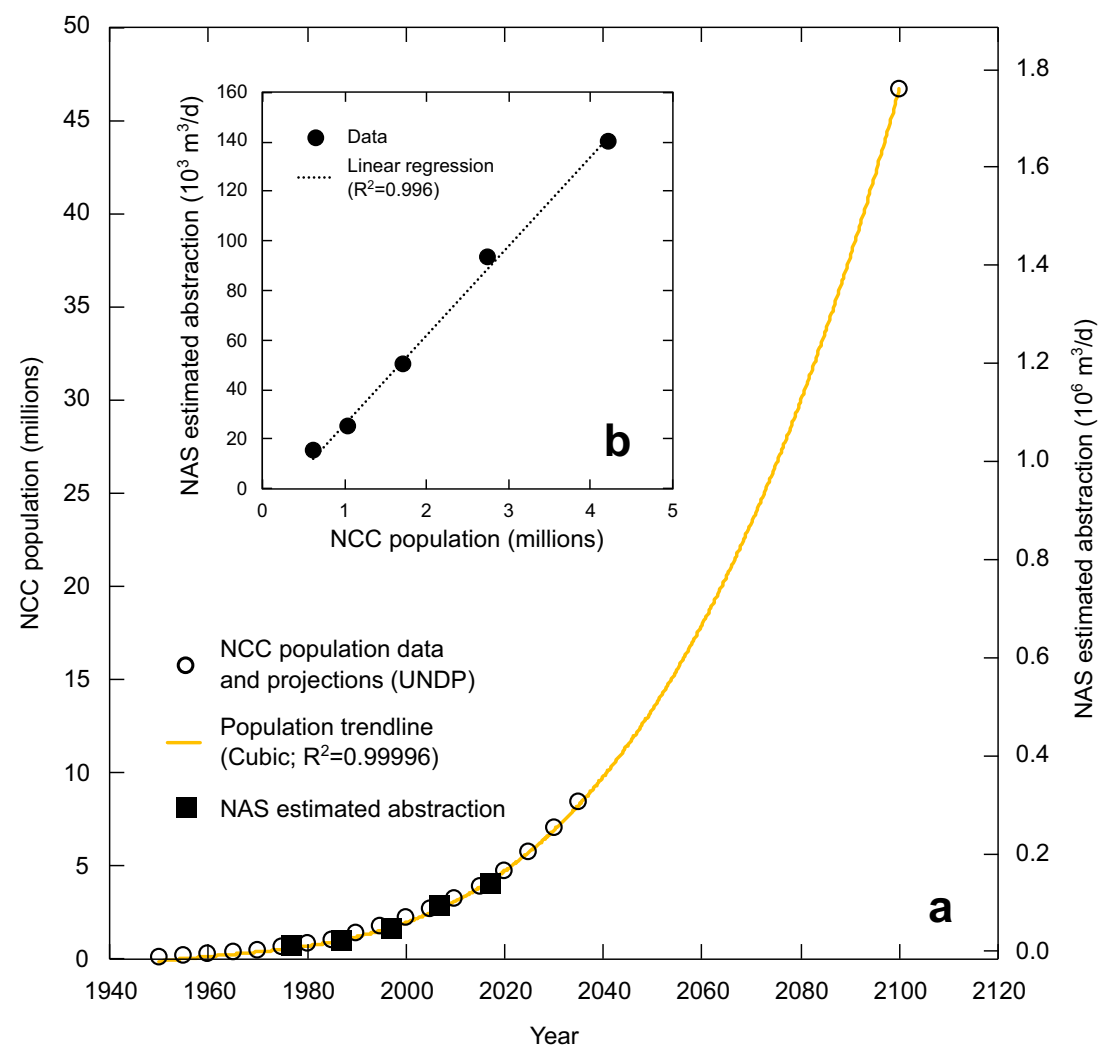


is almost perfectly cubic $\left(R^{2}=0.99996\right)$. This further suggests that, assuming that groundwater demand continues to follow the Nairobi demographic trend; demand will reach over 1.7 million $\mathrm{m}^{3} /$ day by 2100 . This correlation between NAS estimated abstraction and NCC demographics was used to project future groundwater abstraction in the groundwater model (scenario GWDS; section 'Future scenarios').

\section{Groundwater level time series}

The 10-year records of monthly groundwater monitoring in the WRA observation wells (Fig. 3b) are shown in Fig. 8. There are clear long-term decreasing trends for all eight wells that were not being substantially influenced by local high frequency pumping variations. Linear trend analysis showed high significance $\left(R^{2}\right.$ ranging $\left.0.55-0.90\right)$ for wells the least affected by pumping schedules (Hillcrest, Kabansora, KICC, St Lawrence and Trufoods). The long-term, linearly decreasing, trend is a clear indication of regional depletion of the NAS. Groundwater levels from the monitored boreholes within NCC are shown to be declining at a rate ranging between 5-

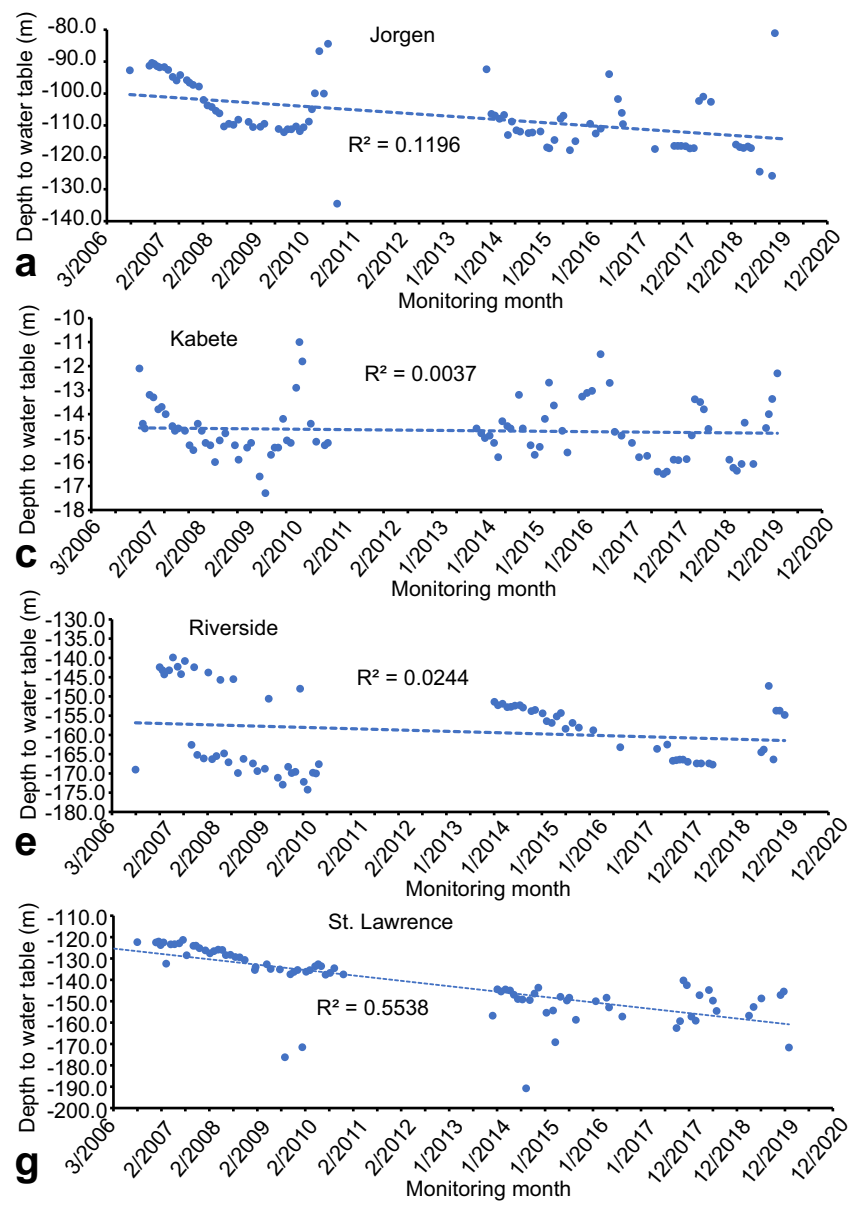

Fig. 8 Long-term trends of declining groundwater levels (with linear trendline and corresponding $R^{2}$ values) as revealed by $2007-2020$ monthly records of depth to groundwater level measured in eight representative monitoring boreholes of the WRA characterised by minimal influence of
$2 \mathrm{~m} /$ year. Across the monitored wells, the mean decline rate is $0.43 \mathrm{~m} /$ year $(4.3 \mathrm{~m} /$ decade $)$ since 2007 . The decline had a slight recovery around 2010 for most stations due to reduced pumping activities of the wells as recorded from WRA well monitoring forms. The sharp punctual anomalies are the result of unstable recovery periods before water levels are captured as all the boreholes reported here are production wells but with agreement between the owners and WRA, borehole owners are expected to stop the pumping $24 \mathrm{~h}$ before monitoring. It is possible that this agreement is not being fully implemented; hence, the observed sharp variations in the observed trends.

\section{Spatio-temporal water-table evolution}

Piezometric maps for different years (1950, 1960, 1970, 1990 and 2017) showed that over time, piezometric contours tend to shift towards the opposite direction of the groundwater flow, i.e. westward (Fig. 9), which again indicates a general decline in groundwater levels. Contour maps for years 1990 and 2015 were well constrained as groundwater observation data are well distributed spatially. The effect of pumping is clearly observed
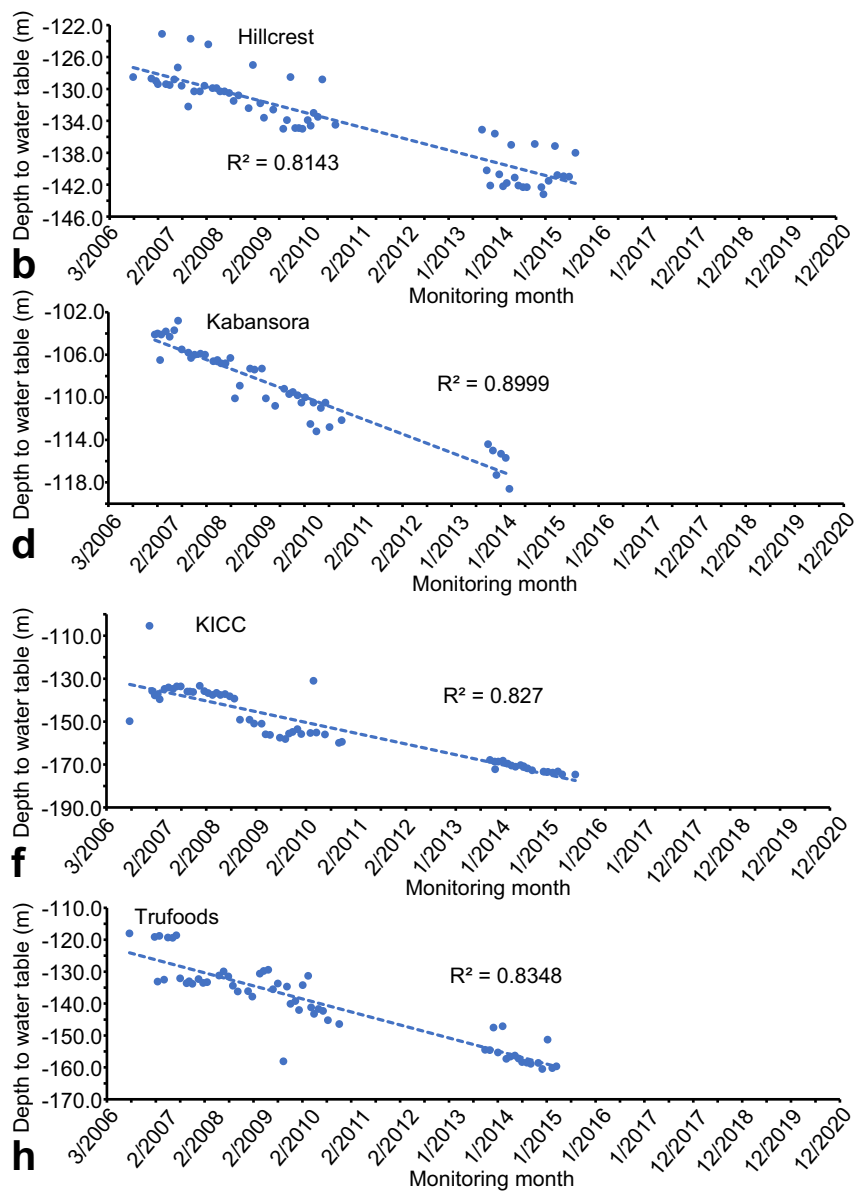

short-term pumping schedules (although punctually visible in wells at Hillcrest, Riverside and Trufoods, shown in $\mathbf{b}$, e and $\mathbf{h}$, respectively). See Fig. 3 for well locations 

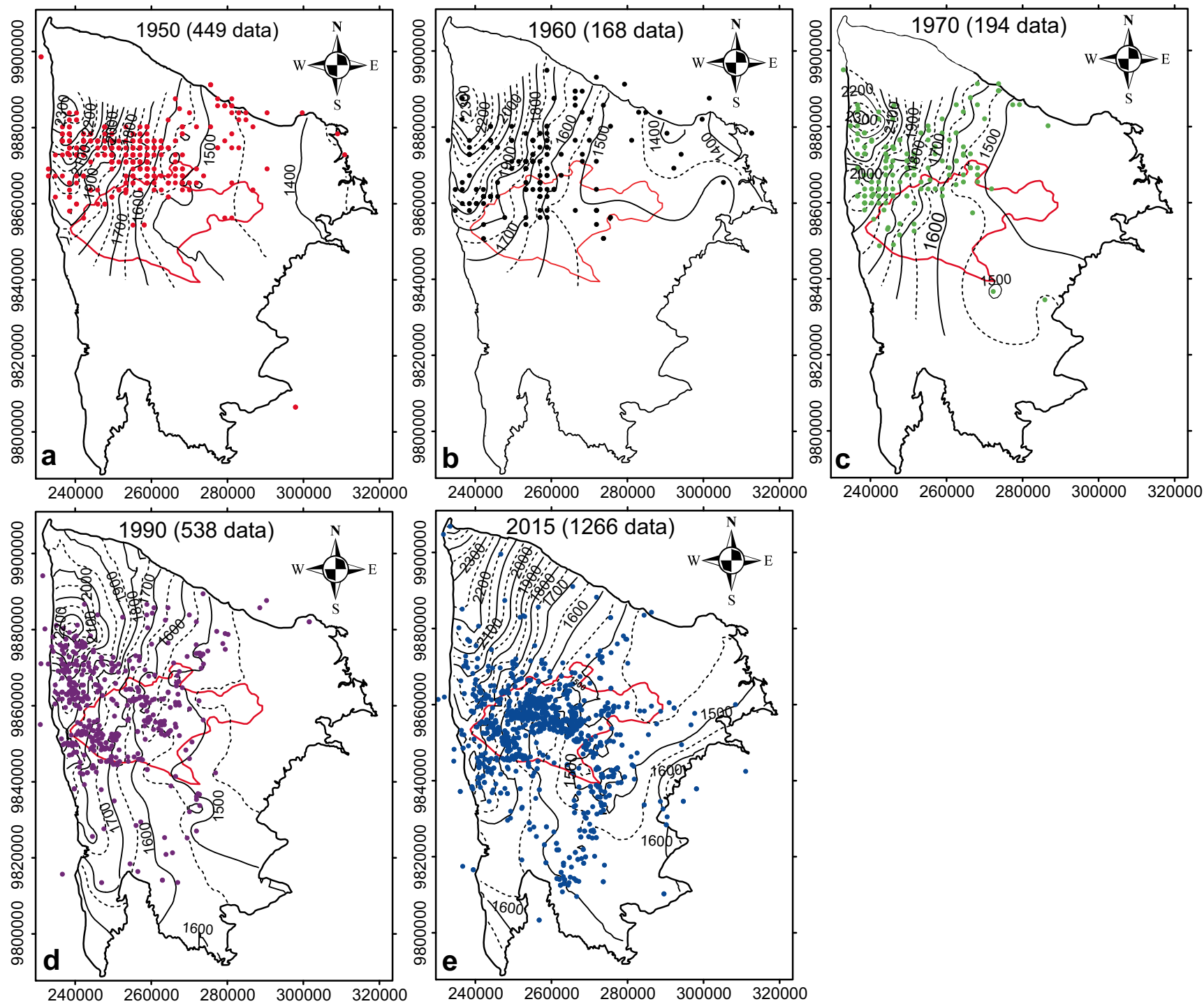

Fig. 9 Kriged (contours) piezometric maps of different successive historical periods - a 1950, b 1960, c 1970, d 1990, and e 2015-with indication of locations of corresponding observation boreholes. Polylines represent groundwater head contours, with plain and dashed lines

representing main $(100 \mathrm{~m})$ and intermediate $(50 \mathrm{~m})$ head contours intervals, respectively. Red polygon represents the Nairobi City County boundary

in NCC, characterised by a general depression of the piezometric surface. It is evident that the potential lines in early years $(1950,1960$, and 1970) are relatively smooth demonstrating the natural groundwater gradient of the region with groundwater flowing from west to east. The 1990 and 2015 potentiometric surface map however produced more distorted potential lines, resulting from more local drawdown due to borehole abstraction. More specifically, the distorted potential lines are observed within the boundary of NCC where borehole density is highest and increasing at an alarming rate.

Overall, throughout the whole observation period, interpolated maps showed a general piezometric inflexion highlighting convergent groundwater flow in the lower part of the study area where the main permanent rivers are situated, which confirms that groundwater is discharging into the surface-water drainage network in this part of the catchment. The relative coarse resolution of interpolated maps, however, does not allow for accurately depicting the interactions between surface and groundwater at the scale of individual streams and rivers.

Maps of change in water-table depth between consecutive dates and throughout the whole observation period show some localised areas with rising water levels likely indicating increased recharge; however, the declining water levels indicate an overwhelming general groundwater depletion (Fig. 10). This depletion is particularly clear, and ubiquitous, between 1990 and 2015, with a general decline of more than $50 \mathrm{~m}$ in places; the period during which abstraction has been multiplied by about 3.5 (from about 40,000 to $140,000 \mathrm{~m}^{3} / \mathrm{day}$; Fig. 6). In addition, the average groundwater decline since 1950 below Nairobi City Council is summarised in Table 4 . 


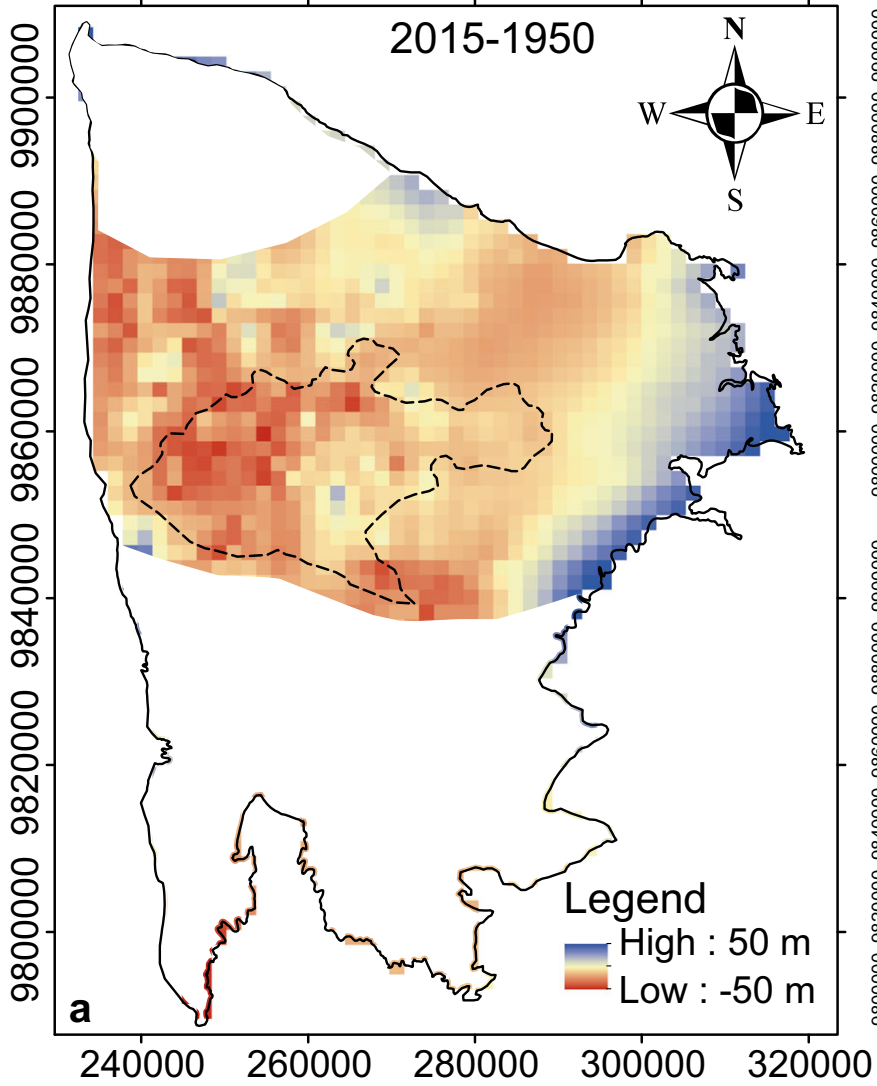

Fig. 10 Kriged (raster) maps of groundwater level change for different periods with blue areas indicating rising water levels (i.e. recharge) and red indicating falling water levels (i.e. depletion): a entire period 1950

\section{Groundwater numerical modelling and future abstraction scenarios}

\section{Model calibration results}

During trial-and-error model calibration, values of hydraulic conductivities were adjusted consecutively within the range of reported values for each geological unit (Fig. 11a,b). All the calibrated geological units' hydraulic conductivity values, with the exception of the Athi sediments, fall within the 25-75\% percentile range of data collated from borehole completion reports for the respective aquifer units, including for the most extensively tapped Kapiti formation for which the calibrated $\mathrm{K}$ is close to the median observed $\mathrm{K}$. The calibrated $\mathrm{K}$ for the
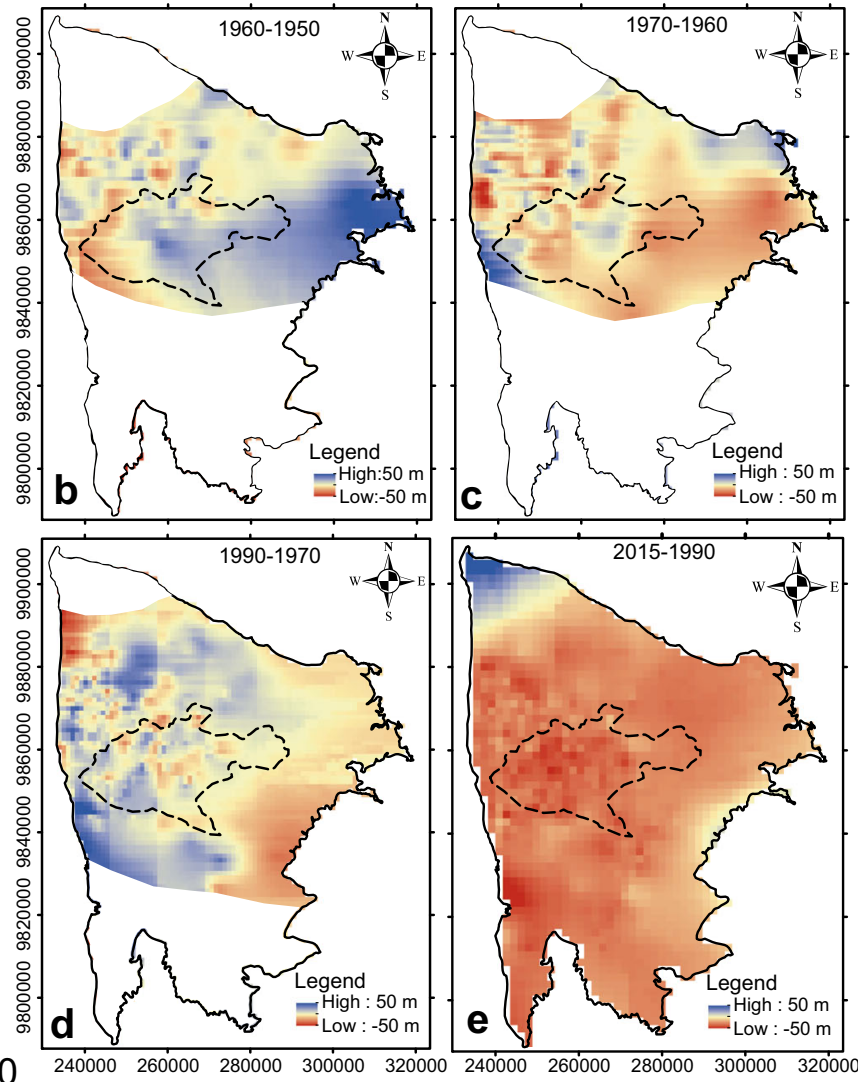

2015; b period 1950-1960; c period 1960-1970; d period 1970-1990; and e period 1990-2015. Dashed contour line outlines the Nairobi City County area

Athi sediments falls within the total observed range but near the upper end of it. This is due to the observed $\mathrm{K}$ values predominantly reflecting the lower, less permeable parts of the Athi sediments present in the Nairobi City area in which most boreholes tapping this unit are drilled (Fig. 2). Regarding storage properties, from an applied initial value of $4.1 \times 10^{-3}$ for both specific storage Ss and specific yield Sy, a uniform Ss value $1 \times$ $10^{-5}$, and Sy values of 0.01 for lower aquifer formations and 0.1 for upper aquifer formations, along with semiconfining conditions below the Athi sediments (Fig. 11c), finally produced the best fit to head observations (Fig. 11d) which was deemed reasonable. The overall satisfactory model fit, including for recent years in most parts of high abstraction areas of the NAS midlands, further supports the initial assumption made
Table 4 Quantification of mean groundwater level change $(\mathrm{m})$ underneath the Nairobi City County (NCC) area indicating continuously falling levels (depletion). $S D$ standard deviation

\begin{tabular}{llllll}
\hline Period & Min water level & Max water level & $\begin{array}{l}\text { Mean water } \\
\text { level }\end{array}$ & $\begin{array}{l}\text { SD of } \Delta \text { mean water } \\
\text { level relative to } 1950\end{array}$ & $\begin{array}{l}\Delta \text { mean water level } \\
\text { compared to 1950 }\end{array}$ \\
\hline 1950 & 1,355 & 1,885 & 1,592 & 0 & 0 \\
1970 & 1,415 & 1,888 & 1,589 & 2 & -3 \\
1990 & 1,409 & 1,896 & 1,584 & 6 & -8 \\
2015 & 1,404 & 1,863 & 1,556 & 26 & -36 \\
\hline
\end{tabular}



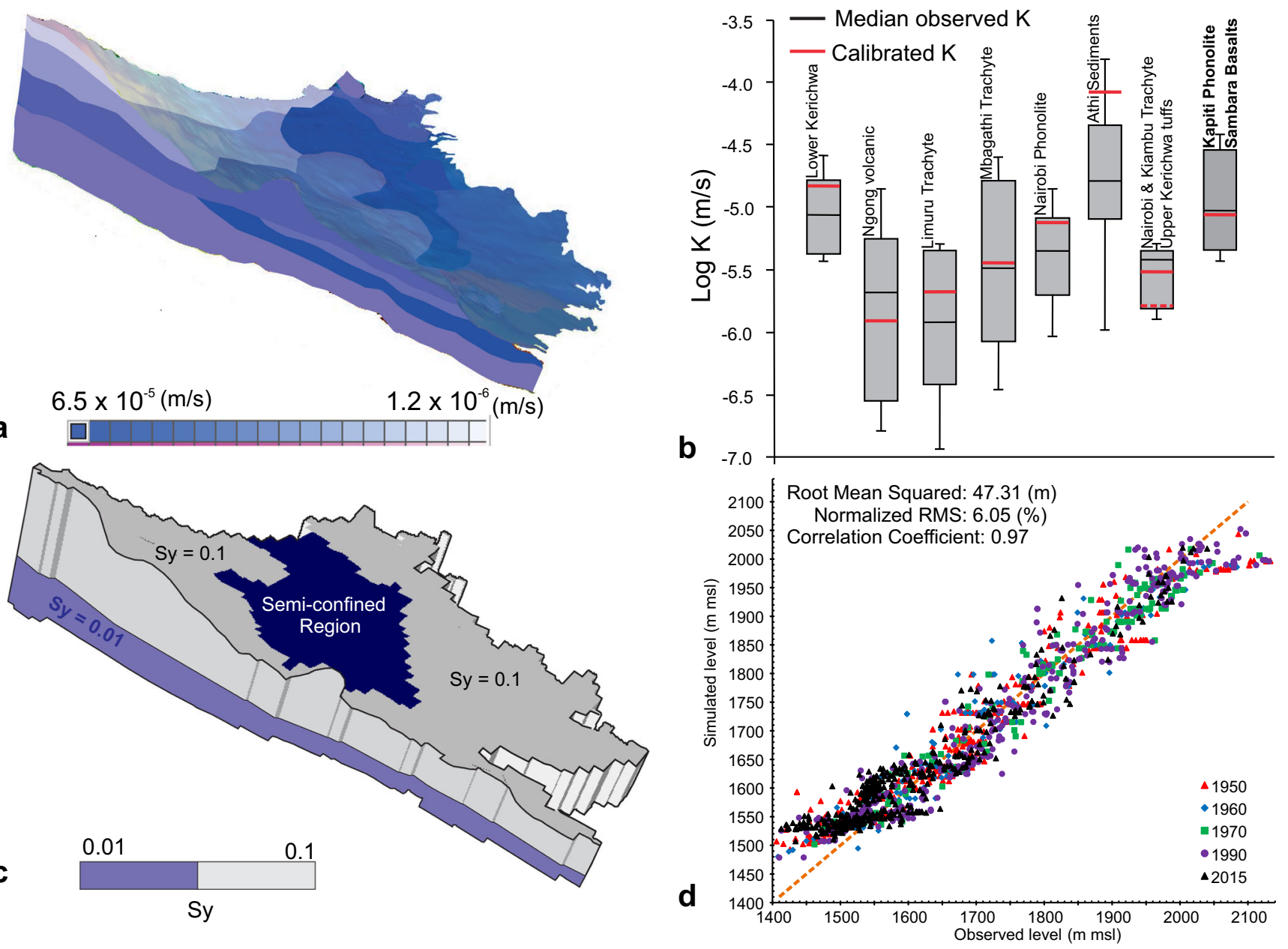

a
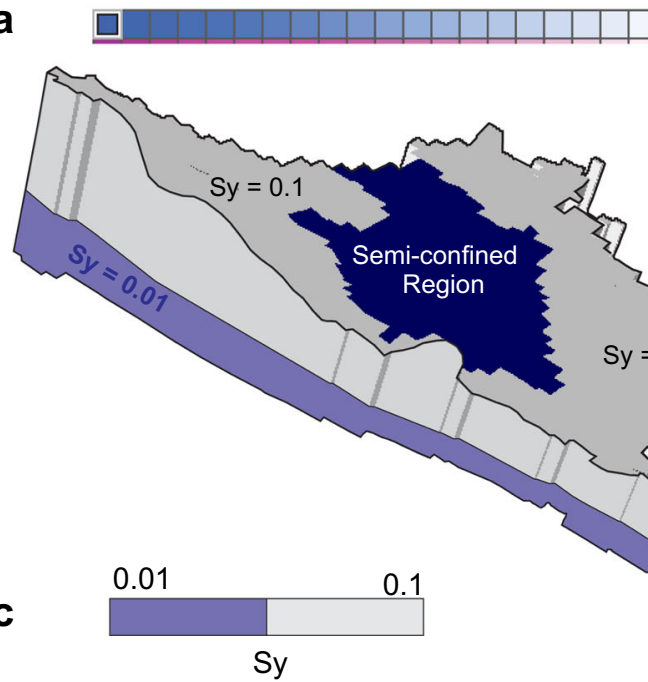

Fig. 11 Groundwater model parametrisation and calibration: a 3D distribution of (final calibrated) hydraulic conductivities $(\mathrm{m} / \mathrm{s})$; $\mathbf{b}$ observed (box plots) versus calibrated (red line) K-values for each NAS hydrogeological unit (the Upper Kerichwa unit has been calibrated separately as indicated by a dashed red line; the Kapiti phonolite, shown in

on the average abstraction rate per borehole and the resulting total groundwater abstraction and trend for the NAS.

\section{Long-term simulation results}

Figure 12 plots the aquifer water budget (fluxes) evolution over the historical and future time periods, using the best model (two-layer Sy 0.01-0.1) as reference, and the two alternative min-max models (uniform Sy of 0.01 and 0.1 respectively) to illustrate model output uncertainties associated with uncertainty in storage values. In all models, the groundwater discharge in rivers (computed as drains), i.e. baseflow (Fig. 12b), shows a decline over time concurrent with increasing groundwater abstraction (Fig. 12a). This suggests that aquifer depletion is likely to cause a decrease in baseflow resulting in a detrimental impact on environmental flows and groundwater dependent ecosystems. As abstraction increases, aquifer storage and water levels keep declining, which bold font, and to a lesser extent the Athi sediments are the main aquifer units being exploited); $\mathbf{c} 3 \mathrm{D}$ distribution of best Sy values with indication of aquifer's semiconfined region; and $\mathbf{d}$ fit between simulated and observed groundwater levels for the period 1939-2018 (1,520 records)

propagate laterally, triggering a decline in groundwater discharge to the drainage network. In future scenarios, the impact is severe under the GWDS groundwater-dependent scenario as water needs are met by continued increasing groundwater abstraction. If the trend continues, perennial drainage networks and springs may change to ephemeral waterbodies mainly depending on surface runoff from intense rains and local, low storage perched aquifers. This detrimental effect is less pronounced with the CWSS scenario where groundwater abstraction is capped from 2018 onwards and complemented by remote water transfer to meet increased water needs. This scenario slows the rate of declining baseflows and stabilizes the rate of change in aquifer storage. In this scenario, leaking pipes further contribute to recharge, because more water is brought from outside the NAS through pipelines embedded beneath the near surface.

In more detail, modelled flow and groundwater level outputs show that their relative uncertainty, resulting from 


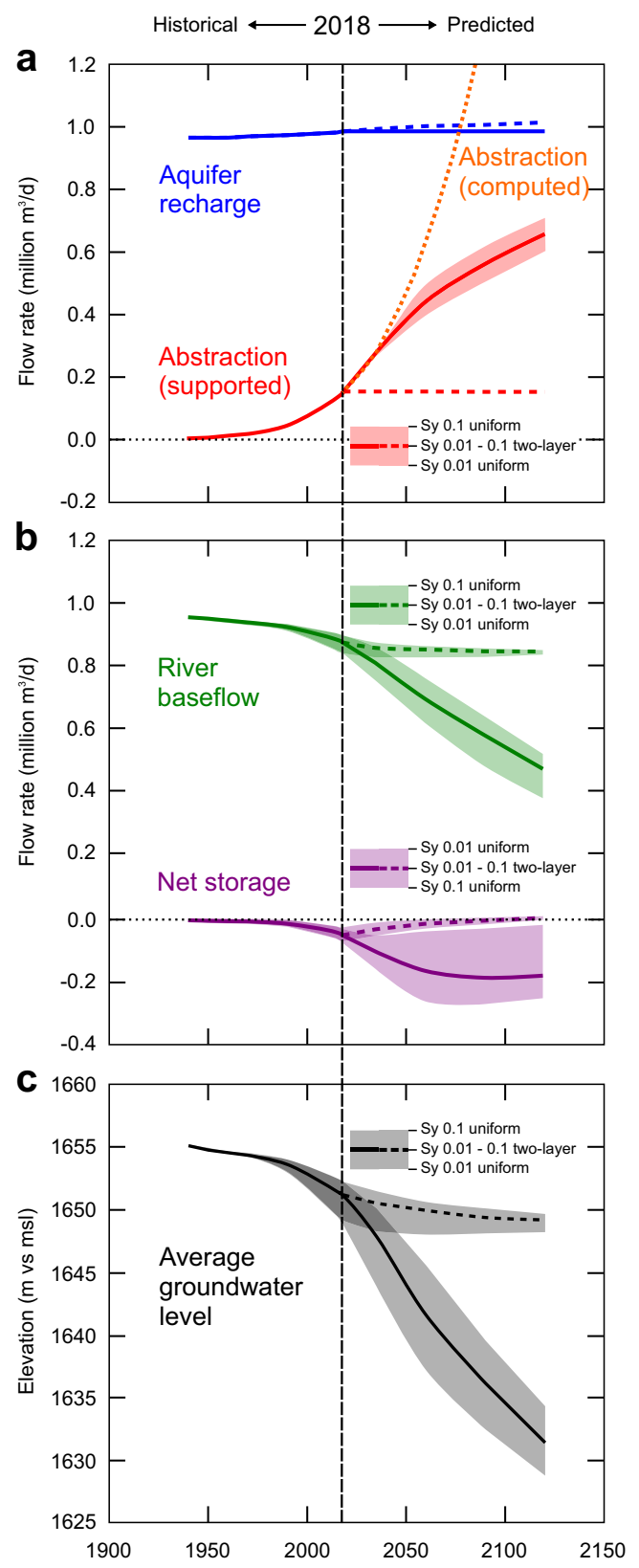

Fig. 12 Evolution of simulated water budget (volumetric flow rates) and spatially averaged groundwater levels for historic situations and for future projections under scenarios GWDS (solid line) and CWSS (dashed line); a model inputs (boundary conditions), i.e. recharge (blue) and abstraction (orange, projected and computed; red, actually supported by the model); b model outputs, i.e. baseflow and net storage change with envelope (i.e. error margin) generated from use of min-max values for specific yield; and $\mathbf{c}$ simulated groundwater levels spatially averaged across the model domain

uncertainties in aquifer storage values (Sy), increases with time, starting from low uncertainty in 1940 when the system is assumed to be in quasi steady state, to highest uncertainty in 2120 at the end of the GWDS scenario. Interestingly, in the GWDS scenario, from years 2035-2040, the model is not able to support the applied abstraction (projected cubic growth) with many of the shallowest wells, especially in the NCC area, losing productivity and/or drying up as a result of lowering water tables. This is reflected in Fig. 12a by the deviation of model (actual) abstraction from the projected (applied) abstraction, which rather follows a logistic growth, as typical from systems with limited resources. This deviation is higher with lower aquifer storage capacity, i.e. supported abstraction is higher with Sy 0.1, than with two-layer Sy 0.1-0.01, which is also higher than with Sy 0.01. For the CWSS scenario, uncertainty decreased again after 2018 due to the maintenance of constant abstraction resulting in a progressive return to quasi steady state. For both scenarios, the max Sy value (0.1) enables the aquifer to best support the increasing abstraction through change in storage, which results in a lower impact on baseflow. In contrast, with the min Sy value (0.01), the decrease in baseflow is more severe due to reduced release of water from aquifer storage. In the best model which has decreasing Sy with depth (0.1 in upper portions vs 0.01 in lower portions) corresponding to intermediate conditions between uniform max-min Sy values, the simulated total decrease in baseflow since the beginning of large-scale groundwater development in the 1950s is $9 \%$, with a net storage loss of 1.5 billion $\mathrm{m}^{3}$. By 2120 in the GWDS scenario, baseflow further decreases by almost half (49\%) of its value in 1940, with a net storage loss of 10.5 billion $\mathrm{m}^{3}$. In the CWSS scenario, baseflow stabilises to a value of $12 \%$ decrease since 1940 and storage recovers (net storage returns to close to zero) aided by the increasing recharge resulting from leaking pipes associated with increasing outsourced water supply.

In terms of groundwater levels, both scenarios display a declining average water table as shown in Fig. $11 \mathrm{c}$ with slower decline being experienced when conjunctive water supply (capped groundwater abstraction and imported water supplies) is initiated. The 2018 average groundwater levels dropped by about $4 \pm 1 \mathrm{~m}$ since 1940, which corresponds to about $5 \pm$ $0.1 \mathrm{~cm} /$ year.

Spatial changes in simulated groundwater levels for the best model (two-layer Sy) and respective scenarios (GWDS and CWSS) are further presented in Fig. 13, which illustrates a regional rather than localised depletion, as consistently demonstrated by observations shown in Fig. 10. However, a greater depletion is experienced in the west and central region of the Greater NCC area. In the central region this is evidently due to the high population density with greater groundwater demand and high borehole density resulting in over-exploitation, which is projected to get worse, with most areas having no piped water supply (Karen, Rongai, and the neighbouring town of Kikuyu). The depletion of the western region is the hydrodynamic effect of the central depletion that lowers upgradient groundwater levels due to the decline of the piezometric base level in the central region. In 2120, simulated depletion is much higher for scenario GWDS than CWSS, by up to $24 \pm 3 \mathrm{~m}$ of water-table decline on average for the former, i.e. six times this of 2018 , as compared to $6 \pm 1 \mathrm{~m}$ for 

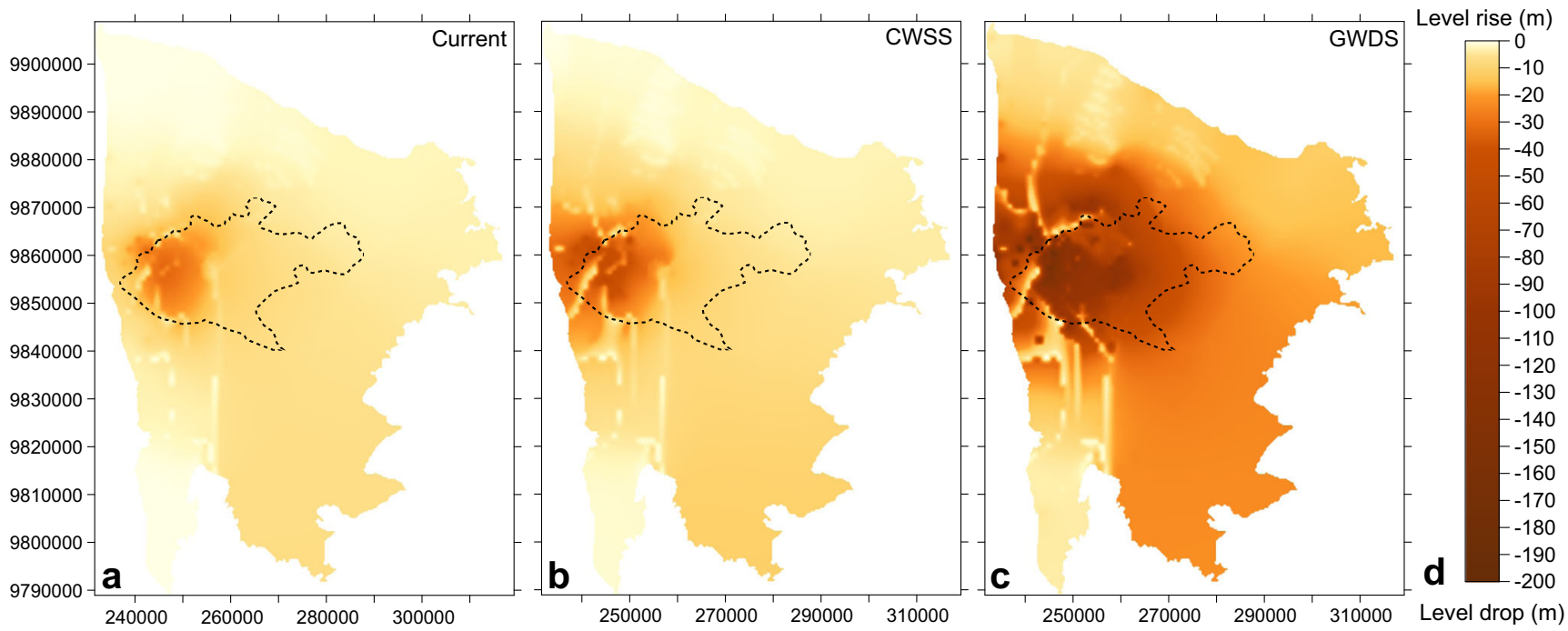

Fig. 13 Modelled changes in groundwater levels for the historical period and future scenarios (best model with layered Sy 0.01-0.1): a changes in recent period (2018) compared to 1940 levels; b simulated changes in

2120 (versus 1940) under conjunctive water supply scenario (CWSS); c changes in 2120 (versus 1940) under groundwater-dependent scenario (GWDS)

the latter (Fig. 10). This means a further 20 and $2 \mathrm{~m}$ decline as compared to 2018 for GWDS and CWSS scenarios, respectively. When looking in more detail at the spatial distribution of groundwater declines, however (Fig. 13), the total watertable drop below and immediately upgradient of Nairobi County reaches a max estimate of $200 \mathrm{~m}(\sim 1 \mathrm{~m} /$ year, continuing) in 2120, under scenario GWDS. For recent times (2018), the model estimates an average value of decline of around $30 \mathrm{~m}$ (max simulated value $46 \mathrm{~m}$ ) across NCC tapped areas. This is broadly consistent with well observations within the NCC (36 $\mathrm{m}$ in average in 2015, Table 4), although suggesting, on the conservative side, a possible overall underestimation of depletion by the model.

As a result of both regional and local depletion, most springs, especially for scenario GWDS in the west are expected to experience decreased water discharge or may even cease flowing during dry seasons. The recharge from leaking supply pipes is contributing positively to groundwater storage capacity around the NCC area even though it is overshadowed by abstraction. This observation encourages groundwater artificial recharge as a way of restoring declining NAS groundwater levels.

\section{Discussion}

This study provided an overview of the historical evolution of the NAS groundwater resource since its large-scale development was initiated in the 1950s, along with an assessment of its likely future evolution over the next 100 years under two scenarios of (1) continuing groundwater development and (2) development of conjunctive water supply.

\section{Hydrogeological conceptual model of the NAS}

The synthesis of existing hydrogeological data for the NAS (borehole logs, hydraulic tests, groundwater levels, abstraction records, land use and climate) along with new geophysical and isotope data (cf. ESM) provided an updated hydrogeological conceptual model of the NAS, including aquifer heterogeneity, confinement and boundary conditions including spatial controls on recharge. The aquifer in particular suffers from a lack of quantitative and reliable information on groundwater recharge and storage properties which are general issues in the African continent as acknowledged by, e.g. Edmunds (2012) and MacDonald et al. (2012), who highlighted in particular that groundwater storage is omitted in all African groundwater resource assessments. Thus, both storativity and recharge have been better constrained in this work through model calibration. The modelling in particular emphasises the role of the lower Athi sediments as a (semi) confining unit for the underlying heavily abstracted volcanic aquifer. Calibrated values of specific yield (0.01-0.1 decreasing with depth) and specific storage $(1 \times$ $10^{-5} \mathrm{~m}^{-1}$ ) are consistent with the ranges of values observed elsewhere in volcanic environments-i.e., as reported by, e.g. Heath (1983), Batu (1998) and Rotzoll et al. (2007) in volcanic rocks from lab experiments and in situ hydraulic testing. The river system was applied as a drain boundary condition since they are gaining channels and their base flows are maintained by aquifer discharges. The drain package ensured that, whenever groundwater level rises above the applied river bottom during modelling, it then discharges into the drainage network. This has the limitation that it did not allow for the accounting of episodic groundwater recharge from river channels during floods resulting from extreme rainfall, which is 
known to be an important contributor to annual recharge in Sub-Saharan Africa (e.g. Taylor et al. 2013). The present approach nevertheless is deemed reasonable for the large timescale (multidecadal trends) considered in this study, including for recharge assessment. Analyses on shorter (seasonal) timescales, however, would require more accurate conceptualisation of groundwater/surface-water interactions including full coupling between surface and sub-surface hydrological models.

\section{Observed and modelled drivers of groundwater depletion}

Hydrogeological data and models have quantified the major impact on groundwater depletion exerted by increasing abstraction as a result of growing population and urbanisation in Nairobi which concurs with findings from Foster et al. (2018) for other large African cities. Annual climatic data do not show significant long-term trends, which suggests that abstraction is the dominant driver for the depletion observed over the study period. Schaeffer et al. (2013) and Powell and Chadwick (2018), recognized the uncertainty surrounding climate projections in the East Africa region, and the impact on Kenyan and East African groundwater resources. Further analysis needs to be conducted on higher temporal resolution climate datasets to explore the role of shorter-term climate extremes and variability on groundwater recharge such as ENSO extreme rainfall and flood events, which are observed to be increasing in magnitude and frequency and have been shown to positively contribute to recharge (e.g. Cuthbert et al. 2019). Conversely, ENSO droughts might result in an acceleration of groundwater development during periods of severe water scarcity, as evidenced by the recent data clearly showing an increase in borehole permit applications during dry years. This increased reliance on groundwater resources during dry periods in Eastern Africa has also been reported by Ferrer et al. (2019) in coastal Kenya and MacDonald et al. (2019) in northern Ethiopia, attributed to the need for climate-resilient, permanent water supply.

\section{Spatial patterns of groundwater depletion}

Hydrogeological data and modelling also revealed that the portion of the aquifer directly underlying the Nairobi City area is the most severely affected by groundwater decline due to the large density of abstraction boreholes, which is also in line with observations in other East African cities such as Addis Ababa and Dar es Salaam (Adelana et al. 2008). However, Nairobi City groundwater decline also affects a more extensive upland area immediately upgradient. In the most depleted areas, groundwater level declines were observed to reach over $30 \mathrm{~m}$ in average as compared to predevelopment conditions before the $1950 \mathrm{~s}$, and are predicted to reach over $200 \mathrm{~m}$ locally within the next 100 years if abstraction continues at the same rate. The model however is shown to locally overestimate some water levels for the recent years in areas with low water-table elevation, below NCC, which means there is a general underestimation of depletion over the last decade. This could be due to an underestimation of abstraction rates (which may be locally higher than the assumed $20 \mathrm{~m}^{3} /$ day per borehole) and/or the number of boreholes for the recent years and suggests that the future GWDS simulations possibly provide a conservative estimate of depletion. Nevertheless, the model highlights the possibility that the shallowest boreholes can and will further dry up or become less productive as water level drops (especially in NCC area). This is already observed, through the increasing number of complaints by borehole owners to the WRA offices in Nairobi reporting drying up of older shallow boreholes (less than $200 \mathrm{~m}$ deep). This also prevented the model to support the applied increasing abstraction (cubic growth) for the groundwater dependent scenario beyond 2035-2040. Currently, in order to protect existing wells, the WRA is recommending that new boreholes be drilled down to more than $300 \mathrm{~m}$ and upper aquifers sealed up. The possible increase in borehole dry up/decrease in well productivity in the long term might either lead to a stabilisation of the depletion over time (as observed through numerical modelling) or perhaps (more likely) a lateral expansion of development via drilling further away from NCC, which implies that depletion might rather expand laterally rather than locally beneath NCC. The modelling only considered increasing abstraction in the immediate surroundings of current abstraction areas, mostly in (peri-)urban areas where most boreholes are located. If drillings expand further away from these areas, together with spatially expanding urbanisation, the NAS might be able to meet the projected groundwater demand longer, although with a higher and spatially more extensive expected impact on baseflow and groundwater levels.

Localised depletion of groundwater in the NCC area generally concurs with the observations by Adelana et al. (2008) and Foster et al. (2018) in other major African cities such as Addis Ababa, Abidjan, Cape Town, Dakar, Lagos, and Lusaka for which underlying aquifers are also experiencing depletion due to increased demand being sustained by groundwater over-abstraction. The observed and modelled average groundwater level decline in NAS of roughly $5 \mathrm{~cm} /$ year is higher than the decline rate of $1.4 \mathrm{~cm} /$ year previously reported for Southern Kenya by Nanteza et al. (2016) through analysis of GRACE data in the wider East Africa. This apparent disagreement is to be attributed to the large spatial footprint of GRACE-derived storage changes $\left(\sim 160,000 \mathrm{~km}^{2}\right)$ which do not have sufficient resolution for (sub) regional depletion as taking place in the NAS. This shows the importance of local to regional scale in situ groundwater data and analysis for 
characterising and managing groundwater depletion associated to extensive groundwater development in rapidly expanding cities. The NAS groundwater level declining rates are broadly similar to recently reported declines in the Kenyan south coast aquifer system, which range $2.5-7.5 \mathrm{~cm} /$ year (1$3 \mathrm{~m}$ in the last four decades; Oiro and Comte 2019).

\section{Modelled long-term aquifer budget and future man- agement scenarios}

Future model simulations provided insight on projected longterm aquifer budget under two alternative groundwater management scenarios - continuing groundwater development at current exponential rates (scenario GWDS), capping further groundwater development and meeting future demands by supplementing with external water supplies piped from outside the Athi basin (Tana basin). Simulations showed that abstraction is a major disruption on the entire water budget as it lowers the environmental flows (reduced baseflow) and reduces aquifer storage; hence, resulting in aquifer depletion, which will likely worsen in the future as groundwater abstraction increases. As baseflow/environmental flow decreases, permanent rivers might begin to fragment to a possibility of becoming intermediate seasonal rivers, a case that MainaGichaba (2013) attributes to human activities and natural variability caused by climate change in Kenya. It may also lead to drying up of wetlands sustained by groundwater discharges as observed in Kiboko swamps area near the town of Limuru, Kenya which used to be occupied by hippos but is not anymore due to reduced water coverage and volume. Land subsidence around the NCC built-up areas may also be experienced in the future if groundwater levels continue to drop and infrastructure development increases. Foster and Tuinhof (2006) already raised this issue for the Nairobi area but land subsidence has not been reported so far.

\section{Impact of urban expansion on groundwater and surface water}

Increased abstraction of groundwater in the NAS has been a direct result of increased water demand associated with population growth, as well as land use change which has dictated the pattern, increase, and spatial distribution of groundwater abstraction points. In the NAS area, increased infrastructure development (surface sealing) has also tremendously increased flooding during the bi-modal rainy seasons (Baariu 2017). Increased infrastructure development and residential housing on former agricultural and open lands has increased run-off during rainy seasons due to increased sealed surfaces, which is expected to become more frequent as urbanisation continues and also has implications for water quality. Human activities in these changed areas can also increase the risk of pollution of the run-offs and downstream surface-water bodies (rivers and wetlands) fed by them as sewer systems have lagged behind development in Nairobi, and in most cases, manholes spill and mix with run-offs (WRA 2020). Though flooding is also associated with the danger of water-borne diseases and deaths due to collapsing houses in informal settlements, it also promotes recharge in downstream floodplain areas through delayed run-off allowing infiltration to take place (Oiro et al. 2018); thus, infiltration of polluted flood water can also be a source of contamination to groundwater. Leaking sewage from poorly constructed septic tanks in (peri) urban areas is a threat to groundwater quality underlying these areas, which, if not checked, could make the NAS system nonpotable in the near future (WRA 2020). As a result of these processes associated with urban surfaces, increased abstraction of groundwater subsequently supplied to urban areas is likely to partly return to groundwater as 'urban groundwater recharge', replacing natural recharge. Although estimated and accounted for in the modelling of the present study, and in itself providing an insignificant contribution to the slowing down of groundwater depletion, the magnitude and particularly the contaminant load of this urban recharge needs to be better quantified and understood.

\section{Conclusions}

Population growth in the NAS area exceeds the national estimated growth rate due to rural-urban migration in Kenya; it has increased following a cubic growth, by a factor of 9 in the last 50 years, from around 700,000 in 1963 to over 6 million currently. For NCC alone, the figures are of 400,000 in 1965 and 4.7 million in 2020. This unprecedented growth has resulted in extremely rapid development of the groundwater resources, indicated by a concurrent growth of borehole numbers and associated abstraction permit application. Associated groundwater abstraction was estimated and found to be highly correlated with NCC population growth; it showed a rapid (cubic) increase by a factor of 10 from $14,500 \mathrm{~m}^{3} /$ day in 1977 to $150,000 \mathrm{~m}^{3} /$ day in 2017 . The increasing water demand in the area is met by groundwater because piped imports of surface-water supply (coming from outside the Tana River catchment) is not reliable and has not been expanded since Kenya gained independence in 1963 . While the analysis of climate data did not show significant changes over the last 50 years, the comparison of borehole permit applications to rainfall records over the last decade provided clear evidence that groundwater development significantly increased during drought periods. Mapping of land use changes showed that urban infrastructure development and associated surface sealing has increased by $70 \%$ between 2000 and 2017 (from 15 to $24 \%$ of the NAS surface). Forest cover has reduced by $23 \%$, from $20 \%$ of the NAS surface in 2000 to $16 \%$ in 2017. Borehole water level data showed a major, generalised long- 
term decline of groundwater levels at an average rate varying from 0.5 to $20 \mathrm{~m}$ per decade observed from monitoring wells. This reflects variability in borehole density, depending on the population and the financial resources of the local residents. Locally, high borehole densities create combined drawdown areas with a large zone of influence.

Numerical hydrogeological models of the NAS using alternative values for aquifer storativity (best fit along with minmax values) confirm extensive regional groundwater depletion and influence on environmental river flows. Simulated regionally declining groundwater levels under the influence of pumping, of $4 \mathrm{~m}$ in average from 1940 to 2018 for the entire NAS and $30 \mathrm{~m}$ in tapped areas beneath Nairobi City, are consistent with the observed declining level for the same period. Groundwater storage has decreased over the years as groundwater levels continue to decline in a manner that is directly proportional to increased abstraction.

With respect to groundwater sustainability and management, the numerical modelling suggests that if the current groundwater abstraction trend continues to the future, permanent rivers and springs being sustained by groundwater discharges may become seasonal with flow only during rainy seasons. The model exposes the possibility where continued abstraction will reduce groundwater storage, estimated as a net loss of 1.5 billion $\mathrm{m}^{3}$ since large-scale groundwater development in the 1950s. Associated lowering of the water table results in reduced river baseflows, estimated at a $9 \%$ decrease on the 70 years' historical period, and $49 \%$ by 2120 if current rates of groundwater development continues. The shallowest abstraction boreholes in the most exploited (peri) urban areas of the Nairobi region will likely further continue losing productivity and dry up. Unless new borehole developments are implemented both deeper and further away from the urban centres, in less exploited areas, the aquifer might not be able to support the projected groundwater demand, and the shortfall between demand and supply is expected to start before the middle of the century. When considering an alternative conjunctive water supply approach for the future, this trend of depletion and decreasing baseflow is minimised as pressure on groundwater is contained. Groundwater management measures are therefore urgently needed to counter the effect of over-abstraction through, e.g. enactment of effective water conservation laws, regulated development, regulated abstraction, managed aquifer recharge, and sourcing for alternative water supplies to allow aquifer recovery. The approach used in this study is broadly transferable to inform many other major cities in Africa and the wider developing world undergoing rapid groundwater development. The findings also demonstrate the importance of longterm in-situ groundwater data and models for mapping and quantifying local to regional-scale groundwater depletion associated with population hotspots in complex hydrogeological settings, in order to address the inaccuracies associated with the lack of spatial resolution of satellite gravity data.
Acknowledgements We warmly thank WRA staff involved in data compilation and acquisition as well as the WRA offices (Nairobi and Kiambu Office) for providing the borehole completion reports and abstraction records. We thank three reviewers for their constructive comments, which contributed to improve the final manuscript.

Funding We acknowledge the Royal Geographical Society (with IBG) Environment and Sustainability Research Grant for supporting the fieldwork activities, and The World Bank/Aurecon AMEI Limited for supporting model scenarios simulations. We are also grateful to the Kenyan Water Resources Authority (WRA) and the University of Aberdeen for jointly supporting Samson Oiro's PhD scholarship.

Open Access This article is licensed under a Creative Commons Attribution 4.0 International License, which permits use, sharing, adaptation, distribution and reproduction in any medium or format, as long as you give appropriate credit to the original author(s) and the source, provide a link to the Creative Commons licence, and indicate if changes were made. The images or other third party material in this article are included in the article's Creative Commons licence, unless indicated otherwise in a credit line to the material. If material is not included in the article's Creative Commons licence and your intended use is not permitted by statutory regulation or exceeds the permitted use, you will need to obtain permission directly from the copyright holder. To view a copy of this licence, visit http://creativecommons.org/licenses/by/4.0/.

\section{References}

Adelana SMA, Abiye TA, Nkhuwa DCW, Tindimugaya C, Oga MS (2008) Urban groundwater management and protection in SubSaharan Africa. Applied Groundwater Studies in Africa. Taylor and Francis, London, pp 231-260

Aeschbach-Hertig W, Gleeson T (2012) Regional strategies for the accelerating global problem of groundwater depletion. Nat Geosci 5:853861. https://doi.org/10.1038/ngeo1617

Baariu PK (2017) Assessment of flood management in South C Ward of Nairobi City County. University of Nairobi, Nairobi, Kenya

Batu V (1998) Aquifer hydraulics: a comprehensive guide to hydrogeologic data analysis. Mar Sci 62:964-965. https://doi.org/ $10.1029 / 98$ eo00453

Bonsor HC, Shamsudduha M, Marchant BP, Macdonald AM, Taylor RG (2018) Seasonal and decadal groundwater changes in African sedimentary aquifers estimated using GRACE products and LSMs. Remote Sens 10(6):904. https://www.mdpi.com/2072-4292/10/6/ 904. Accessed 11/6/2019

Cardoso de Salis HH, Monteiro da Costa A, Moreira Vianna JH, Azeneth Schuler M, Künne A, Sanches Fernandes LF, Leal Pacheco FA (2019) Hydrologic modeling for sustainable water resources management in urbanized karst areas. Int J Environ Res Public Health 16(14):2542

Chen J, Famigliett JS, Scanlon BR, Rodell M (2016) Groundwater storage changes: present status from GRACE observations. Surv Geophys 37:397-417. https://doi.org/10.1007/s10712-015-9332-4

Coleman TI, Parker BL, Maldaner CH, Mondanos MJ (2015) Groundwater flow characterization in a fractured bedrock aquifer using active DTS tests in sealed boreholes. J Hydrol 528:449462. https://www.sciencedirect.com/science/article/pii/ S0022169415004746? casa_token=XKBYHP8tVkAAAAA: 
7FQocDwoWYrQBE3D68tVzlM64DmcJTIJM57DyIZm0qixyr k9pgVXg_YnJEZHwJvv5oJ6dQ0-g. Accessed 13/05/2016

Comte JC, Cassidy R, Obando J, Robins N, Ibrahim K, Melchioly S, Mjemah I, Shauri H, Bourhane A, Mohamed I, Noe C (2016) Challenges in groundwater resource management in coastal aquifers of East Africa: investigations and lessons learnt in the Comoros Islands, Kenya and Tanzania. J Hydrol 5:179-199

Cuthbert MO, Taylor RG, Favreau G, Todd MC, Shamsudduha M, Villholth KG, MacDonald AM, Scanlon BR, Kotchoni DV, Vouillamoz JM, Lawson FM (2019) Observed controls on resilience of groundwater to climate variability in sub-Saharan Africa. Nature 572(7768):230-234

de Graaf IE, van Beek RL, Gleeson T, Moosdorf N, Schmitz O, Sutanudjaja EH, Bierkens MF (2017) A global-scale two-layer transient groundwater model: development and application to groundwater depletion. Adv Water Resour 102:53-67

Doell P, Mueller Schmied H, Schuh C, Portmann FT, Eicker A (2014) Global-scale assessment of groundwater depletion and related groundwater abstractions: combining hydrological modeling with information from well observations and GRACE satellites. Water Resour Res 50(7):5698-5720

Edmunds WM (2012) Limits to the availability of groundwater in Africa. Environ Res Lett 7. https://doi.org/10.1088/1748-9326/7/2/021003

Famiglietti JS (2014) The global groundwater crisis. Nat Clim Change 4: 945-948. https://doi.org/10.1038/nclimate2425

Ferrer N, Folch A, Lane M, Olago D, Odida J, Custodio E (2019) Groundwater hydrodynamics of an eastern Africa coastal aquifer, including La Niña 2016-17 drought. Sci Total Environ 661:575597

Foster S, Tuinhof A (2006) The role of groundwater in the water-supply of Greater Nairobi, Kenya. Kenya Ministry of Water and Irrigation, Nairobi, Kenya

Foster S, Bousquet A, Furey S (2018) Urban groundwater use in tropical Africa: a key factor in enhancing water security? Water Pol 20:982994. https://doi.org/10.2166/wp.2018.056

Gaciri SJ, Davies TC (1993) The occurrence and geochemistry of fluoride in some natural waters of Kenya. J Hydrol 143:395-412. https://doi. org/10.1016/0022-1694(93)90201-J

Gulyani S, Talukdar D, Kariuki M (2005) Water for the urban poor: water markets, household demand, and service preferences in Kenya. Water Supply and Sanitation Sector Board Discussion Paper Series, World Bank, Washington, DC

Heath RC (1983) Basic ground-water hydrology. US Geol Surv Water Suppl Pap 2220

Heath RC (1987) Basic of ground-water hydrology, 4th edn. US Geol Surv Water Suppl Pap 2220

Hoornweg D, Pope K (2014) Socioeconomic pathways and regional distribution of the world's 101 largest cities. Global Cities Institute. https://shared.ontariotechu.ca/shared/faculty-sites/sustainabilitytoday/publications/largest_cities.pdf. Accessed 16/06/2020

Hoornweg D, Pope K (2017) Population predictions for the world's largest cities in the 21st century. Environ Urban 29:195-216. https://doi. org/10.1177/0956247816663557

ISC (2019) National Groundwater Potential Report under Kenya Water Security and Climate Resilience Project

Joodaki G, Wahr J, Swenson S (2014) Estimating the human contribution to groundwater depletion in the Middle East, from GRACE data, land surface models, and well observations. AGU 50:2679-2692. https://doi.org/10.1002/2013WR014633.Received

Knowling MJ, Werner AD, Herckenrath D (2015) Quantifying climate and pumping contributions to aquifer depletion using a highly parameterised groundwater model: Uley South Basin (South Australia). J Hydrol 523:515-530. https://doi.org/10.1016/j. jhydrol.2015.01.081

Koei N (2013) The Kenya National Water Master Plan. JICA, Tokyo
Konikow LF, Kendy E (2005) Groundwater depletion: a global problem. Hydrogeol J 13:317-320. https://doi.org/10.1007/s10040-0040411-8

Kuria Z (2013) Groundwater distribution and aquifer characteristics in Kenya. Develop Earth Surf Proc 16:83-107. https://doi.org/10. 1016/B978-0-444-59559-1.00008-6

Lane M, Thomas M, Odero D (2011) Inventory for all the boreholes drilled with the Nairobi metropolitan. Consultancy services report for Water Resources Management Authority

MacDonald AM, Bonsor HC, Dochartaigh BÉÓ, Taylor RG (2012) Quantitative maps of groundwater resources in Africa. Environmen Res Lett 7:7. https://doi.org/10.1088/1748-9326/7/2/ 024009

MacDonald AM, Bonsor HC, Ahmed KM, Burgess WG, Basharat M, Calow RC, Dixit A, Foster SSD, Gopal K, Lapworth DJ, Lark RM (2016) Groundwater quality and depletion in the Indo-Gangetic Basin mapped from in situ observations. Nat Geosci 9(10):762-766

Maina-Gichaba C (2013) Relief, physiography and drainage. In: Paolo P, Shroder JFJ (eds) Kenya: a natural outlook. Elsevier, Oxford, 375 pp

Mumma A, Lane M, Kairu E, Tuinhof A, Hirji R (2011) Kenya groundwater governance case study. Water Papers, World Bank, Washington, DC

Nanteza J, de Linage CR, Thomas BF, Famiglietti JS (2016) Monitoring groundwater storage changes in complex basement aquifers: an evaluation of the GRACE satellites over East Africa. AGU 52: 9542-9564. https://doi.org/10.1002/2016WR018846.Received

Ochoa-González GH, Carreón-Freyre D, Cerca M, López-Martínez M (2015) Assessment of groundwater flow in volcanic faulted areas. A study case in Queretaro, Mexico. Geofísica Internacional 54(3): 199-220. http://www.scielo.org.mx/scielo.php?script=sci arttext\&pid=S0016-71692015000300199. Accessed 13/05/2016

Odero D (2011) Water Resources Management Authority, Kenya natural resources management project, Study of groundwater recharge to the Kikuyu. Springs, Nairobi, Kenya

Oiro S, Comte JC (2019) Drivers, patterns and velocity of saltwater intrusion in a stressed aquifer of the East African coast: joint analysis of groundwater and geophysical data in southern Kenya. J Afr Earth Sci 149:334-347. https://doi.org/10.1016/j.jafrearsci.2018.08.016

Oiro S, Comte J-C, Soulsby C, Walraevens K (2018) Using stable water isotopes to identify spatio-temporal controls on groundwater recharge in two contrasting East African aquifer systems. Hydrol Sci J 63:1-16. https://doi.org/10.1080/02626667.2018.1459625

Okoth S (2012) Hydraulic Characteristics and Hydrochemistry of Nairobi area, Kenya. MSc Thesis. Technical University of Darmstadt

Powell PD, Chadwick R (2018) Causes of the uncertainty in projections of tropical terrestrial rainfall change: East Africa. J Clim 31:59775995. https://doi.org/10.1175/JCLI-D-17-0830.1

Resende TC, Longuevergne L, Gurdak JJ, Leblanc M, Favreau G, Ansems N, Van der Gun J, Gaye CB, Aureli A (2019) Assessment of the impacts of climate variability on total water storage across Africa: implications for groundwater resources management. Hydrogeol J 27(2):493-512

Rodell M, Velicogna I, Famiglietti JS (2009) Satellite-based estimates of groundwater depletion in India. Nature 460:999-1003. https://doi. org/10.1038/nature08238

Rotzoll K, El-Kadi AI, Gingerich SB (2007) Estimating hydraulic properties of volcanic aquifers using constant-rate and variable-rate aquifer tests. J Am Water Resour Assoc 43:334-345. https://doi.org/10. 1111/j.1752-1688.2007.00026.x

Scanlon BR, Faunt CC, Longuevergne L, Reedy RC, Alley WM, McGuire VL, McMahon PB (2012) Groundwater depletion and sustainability of irrigation in the US High Plains and Central Valley. Proc Natl Acad Sci 109(24):9320-9325

Schaeffer M, Baarsch F, Adams S, de Bruin K, De Marez L, Freitas S, Hof A, Hare B (2013) Climate-change impacts, adaptation challenges and costs for Africa. UNEP, Nairobi, Kenya 
Taylor RG, Scanlon B, Döll P, Rodell M, Van Beek R, Wada Y, Longuevergne L, Leblanc M, Famiglietti JS, Edmunds M, Konikow L (2013) Ground water and climate change. Nat Clim Chang 3(4):322-329. https://idp.nature.com/authorize/casa? redirect_uri=https://www.nature.com/articles/nclimate $1744 \&$ casa t o k e $\mathrm{n}=\mathrm{i}$ D F j W r z 2 v b s A A A A A : WW5DIcidhbBYPf7k76SVeA5G14vBa2niGmFarokcXr qtFcTzBqUY4Ru6PKDSBblPplgzEtBnLke1dd. Accessed 29/10/ 2015

Thomson P, Bradley D, Katilu A, Katuva J, Lanzoni M, Koehler J, Hope R (2019) Rainfall and groundwater use in rural Kenya. Sci Total Environ 649:722-730

United Nations (2018) Population divisionworld urbanization prospects 2018. https://population.un.org/wup/. Accessed August 2020

United Nations (2019) World population prospects 2019: highlights. ST/ ESA/SER.A/423, United Nations, New York

USGS (2018) https://earthexplorer.usgs.gov/. Accessed 16/05/2018
Wada Y (2016) Modeling groundwater depletion at regional and global scales: present state and future prospects. Surv Geophys 37:419 451. https://doi.org/10.1007/s10712-015-9347-x

Wada Y, Van Beek LP, Van Kempen CM, Reckman JW, Vasak S, Bierkens MF (2010) Global depletion of groundwater resources. Geophys Res Lett 37(20)

Wada Y, Wisser D, Bierkens MFP (2014) Global modeling of withdraw$\mathrm{al}$, allocation and consumptive use of surface water and groundwater resources. Earth Syst Dyn 5:15-40. https://doi.org/10.5194/esd-515-2014

Wamwangi E, Musiega D (2013) Geospatial analysis of groundwater fluoride contamination in Embakasi Area, Nairobi. Esri Eastern Africa Education User Conference. Redlands, CA, May 2013, pp $1-15$

World Weather Online (2019) Homepage. worldweatheronline.com. Accessed 11 November 2019

WRA (2020) Nairobi aquifer systems challenges. WRA, Nairobi, Kenya 